\title{
The Demand Requirement in Investment Company Act Shareholder Actions
}

The Investment Company Act of 1940 , as amended, ${ }^{1}$ (ICA) regulates conflicts of interest ${ }^{2}$ that arise in the investment company industry. ${ }^{3}$ Section $36(\mathrm{~b})$ of the ICA provides that "the investment adviser of a registered investment company shall be deemed to have a fiduciary duty with respect to the receipt of compensation for services," and that an action to recover fees paid in breach of this fiduciary duty may be brought "by the [SEC], or by a security holder of such registered investment company on behalf of such company."

115 U.S.C. $\$ \S 80 \mathrm{a}-1$ to -64 (1976 \& Supp. V 1981). An investment company is any association (corporation, partnership, trust, etc.) "by which a number of persons invest funds in a 'company' that is itself engaged in investing in securities." SEC, PUBLIC PolicY Implications of InVEstment Company Growth, H.R. ReP. No. 2337, 89th Cong., 2d Sess. 33 (1966) [hereinafter cited as SEC REPoRT]; see also Investment Company Act of 1940, 15 U.S.C. $\$ 80 \mathrm{a}-3$ (1976). Mutual funds are by far the most common form of investment companies. SEC REPORT, supra, at 43. "A mutual fund is an investment company which offers its shares to the public on a continuous basis and is obligated to redeem the shares on demand at net asset value." Case Comment, Director Termination of Mutual Fund Advisory Fee Suits: Grossman v. Johnson, 62 B.U.L. Rev. 601, 601 n.1 (1982).

2 Some commentators believe that government regulation of investment company authority is an inappropriate response to potential conflicts of interest in the industry. See infra note 32. This comment does not address the theoretical appropriateness of such governmental regulation but explores the problem of excessive fees within the context of the existing statutory framework.

${ }^{3}$ See infra notes 12-38 and accompanying text.

- In relevant part, $\$ 36(\mathrm{~b})$ provides :

For the purposes of this subsection, the investment adviser of a registered investment company shall be deemed to have a fiduciary duty with respect to the receipt of compensation for services, or of payments of a material nature, paid by such registered investment company, or by the security holders thereof, to such investment adviser or any affiliated person of such investment adviser. An action may be brought under this subsection by the Commission, or by a security holder of such registered company on behalf of such company. ... With respect to any such action the following provisions shall apply:

(1) It shall not be necessary to allege or prove that any defendant engaged in personal misconduct, and the plaintiff shall have the burden of proving a breach of fiduciary duty:

(2) In any such action approval by the board of directors of such investment company of such compensation or payments, or of contracts or other arrangements providing for such compensation or payments . . . shall be given such consideration by the court as is deemed appropriate under all the circumstances.

(3) . . . No award of damages shall be recoverable for any period prior to one year 
The investment adviser typically receives as compensation ${ }^{5}$ for his services a percentage of the fund's average net assets. ${ }^{6}$ As mutual funds have experienced dramatic growth in the past ten years, ${ }^{7}$ advisers have in turn experienced a huge growth in fees, ${ }^{8}$ even though economies of scale make the additional cost of managing larger portfolios relatively small. ${ }^{9}$ The sudden escalation of advisory fees prompted many mutual fund shareholders to sue under

before the action was instituted. Any award of damages against such recipient shall be limited to the actual damages resulting from the breach of fiduciary duty and shall in no event exceed the amount of compensation or payment received from such investment company, or the security holders thereof, by such recipient. Investment Company Act of $1940 \S 36(\mathrm{~b}), 15$ U.S.C. $\$ 80 \mathrm{a}-35(\mathrm{~b})$ (1976). (The section is generally referred to as $\S 36(\mathrm{~b})$, its number in the original 1940 Act.).

- The Act prohibits any person from serving as an investment adviser to a registered investment company except pursuant to a written contract. It also requires that the contract "precisely describe the compensation to be paid thereunder." See Investment Company Act of 1940 § 15(a), 15 U.S.C. $\$ 80 a-15$ (a) (1976); see also SEC REPORT, supra note 1, at 88-89. The Act does not specify the amount of an appropriate fee. Id. at 88-89.

- SEC REPoRT, supra note 1, at 10, 88-89 ("The traditional formula has been a flat annual rate of 0.50 percent of the fund's average net assets."); see also Weiss v. Temporary Inv. Fund, 692 F.2d 928, 931 (3d Cir. 1982); Fox v. Reich \& Tang, Inc., 692 F.2d 250, 253 (2d Cir. 1982), cert. granted sub nom. Daily Income Fund v. Fox, 103 S. Ct. 1271 (1983).

' In 1940, when the original Investment Company Act, Pub. L. No. 76-686, tit. I, 54 Stat. 789 (1940) (codified as amended at 15 U.S.C. \$§ 80a-1 to -64 (1976 \& Supp. V 1981)), was enacted, investment company assets totalled about $\$ 2.1$ billion. SEC REPORT, supra note 1, at 1-2. By 1966, when amendments to the Act were being considered, investment company assets had grown to $\$ 46.4$ billion, $\$ 38.2$ billion of which consisted of investments in open-ended mutual funds. Id. In 1972, the first money market mutual fund was started, and by June, 1978 , there was a total of $\$ 6.8$ billion in assets invested in these funds. Gartenberg v. Merrill Lynch Asset Mgmt., 528 F. Supp. 1038, 1041-42 (S.D.N.Y. 1981), aff'd, 694 F.2d 923 (2d Cir. 1982), cert. denied sub nom. Andre v. Merrill Lynch Ready Assets Trust, $103 \mathrm{~S}$. Ct. 1877 (1983); see also N.Y. Times, Dec. 18, 1981, at D9, col. 4. Between 1978 and October, 1982 , mutual fund assets rose from $\$ 55$ billion to $\$ 299$ billion. N.Y. Times, Nov. 2, 1982, at D15, col. 6. Most of these assets were invested in money market funds- $\$ 230$ billion as of October, 1982. Id. By February 24, 1983, assets of the nation's 302 money market mutual funds had fallen somewhat to $\$ 191$ billion. Chicago Tribune, Feb. $25,1983, \S 4$, at 12, col. 1 . The funds boomed because, during this period of high interest rates, these funds, through pooling the resources of numerous investors, enabled small investors "to purchase a diversified portfolio of securities, producing a much higher return than that normally available to the small investor." Note, Termination of Section 36(b) Actions by Mutual Fund Directors: Are the Watchdogs Still the Shareholders' Best Friends?, 50 Fordham L. REv. 720, 720 (1982) (citations omitted). The substantially higher interest rates of money market funds lured depositors away from traditional savings institutions. N.Y. Times, Nov. 2, 1982, at D15, col. 6; see also Gartenberg, 582 F. Supp. at 1041-42.

- In three years, the yearly payments made to the adviser of one fund increased from $\$ 375,000$ to a projected $\$ 3,875,000$. Fox v. Reich \& Tang, Inc., 692 F.2d 250, 252-53 (2d Cir. 1982), cert. granted sub nom. Daily Income Fund v. Fox, 103 S. Ct. 1271 (1983).

- "[O]perating costs decline proportionately as the size of a trust increases." SEC REPORT, supra note 1, at 95 (quoting Merrill Griswold, Chairman of the Board of the mutual fund MIT, testifying at Senate Hearings leading to the passage of the ICA). 
section 36 (b) of the ICA to recover the excess fees and to restore them to the corporate treasury. ${ }^{10}$

Since the procedural requirements of section 36(b) shareholder suits are not specified by statute, a debate has arisen in the federal courts as to whether a section $36(\mathrm{~b})$ shareholder plaintiff must comply with the demand requirement of rule 23.1 of the Federal Rules of Civil Procedure ${ }^{11}$ prior to commencing suit. Rule 23.1 requires shareholder plaintiffs either to make demand on the board of directors of the corporation before commencing a derivative action in an attempt to obtain the remedy they desire or to give an excuse for the failure to make demand. Plaintiffs in section 36(b) actions have advanced two arguments against requiring demand: first, that section $36(\mathrm{~b})$ shareholder suits are not derivative actions; and second, that even if section $36(\mathrm{~b})$ actions are derivative, demand under rule 23.1 would inevitably be futile and should therefore be automatically excused.

This comment will review the structure and purposes of the ICA, particularly section $36(\mathrm{~b})$, discuss the federal cases that have considered the issue of demand in section $36(\mathrm{~b})$ cases, and evaluate the arguments regarding the derivative nature of the section $36(\mathrm{~b})$ suit and the propriety of demand in such suits. It concludes that the language and legislative history of section $36(\mathrm{~b})$ are most easily read as making the shareholder cause of action under that section derivative of an implied cause of action accruing to the directors of the fund. Finding that demand furthers the policy of section $36(\mathrm{~b})$, streamlines derivative suits, and increases opportunities to settle section 36 (b) suits without burdening plaintiff shareholders, the comment also concludes that demand should be required in all section $36(\mathrm{~b})$ suits.

\section{The History of the CurRent Debate}

\section{A. History of the ICA}

Congress passed the Investment Company Act of 1940 in response to concern over "the potential for abuse inherent in the structure of investment companies."12 Mutual funds and other investment companies are characterized by a "unique"13 manage-

${ }^{10}$ E.g., Fox v. Reich \& Tang, Inc., 692 F.2d 250 (2d Cir. 1982), cert. granted sub nom. Daily Income Fund v. Fox, 103 S. Ct. 1271 (1983).

11 See cases cited at infra note 60 (text of rule 23.1).

12 Burks v. Lasker, 441 U.S. 471, 480-81 (1979); see also Tannenbaum v. Zeller, 552 F.2d 402, 406 (2d Cir. 1977), cert. denied, 434 U.S. 934 (1977).

13 S. Rep. No. 184, 91st Cong., 1st Sess. 2 (1969), reprinted in 1970 U.S. Code Cong. \& AD. News 4897, 4898 [hereinafter cited as Senate Report]. 
ment structure; although the funds are nominally independent and supervised by their own boards of directors, they are sponsored and managed by a separate company that acts as the funds' investment adviser. ${ }^{14}$ An investment adviser's control over the fund typically includes organizing and promoting the fund, managing the fund's portfolio, ${ }^{15}$ supervising the business operations of the fund, and even selecting the fund's directors, some of whom may also be directors or officers of the investment adviser. ${ }^{16}$ The extensive control over the fund wielded by the adviser is a matter of necessity, for the fund's directors usually do not possess the expertise needed to manage the fund. The directors' dependence on the adviser is problematic. The directors are often reluctant to terminate an advisory contract for fear of the fund's being left at risk without an adviser. "[T]he forces of arm's-length bargaining do not work in the mutual fund industry in the same manner as they do in other sectors of the American economy,"17 and, as a result, "[t]he relationship between investment advisers and mutual funds is fraught with potential conflicts of interest."18

When it enacted the ICA ${ }^{18}$ in 1940 , Congress sought to prevent abuse of the investment company structure ${ }^{20}$ by requiring that at

14 Id. at 5, reprinted in 1970 U.S. Code Cong. \& AD. NEws 4897, 4901; see also SEC REport, supra note 1, at 8; Case Comment, supra note 1, at 601-02.

15 The portfolio is usually the fund's only asset. SEC REPORT, supra note 1, at 8 .

16 Tannenbaum v. Zeller, 552 F.2d 402, 405 (2d Cir.), cert. denied, 434 U.S. 934 (1977); SEC Report, supra note 1, at 8; Note, supra note 7, at 724; Note, Mutual Fund Advisory Fees-Too Much for Too Little?, 48 FordhaM L. Rev. 530, 531-32 (1980) [hereinafter cited as Note, Mutual Funds].

17 Senatz Report, supra note 13 , at 5, reprinted in 1970 U.S. Code Cong. \& Av. News 4897, 4901; see also SEC REPORT, supra note 1, at 12 ("[N]either cost considerations nor other competitive factors influence a fund's choice of advisers. This is so because mutual funds are formed by, and generally remain under, the effective control of their advisers." (citation omitted)).

18 Burks v. Lasker, 441 U.S. 471, 481 (1979) (quoting Galfand v. Chestnutt Corp., 545 F.2d 807, 808 (2d Cir. 1976)).

10 Prior to 1940 , the basic mechanism for mutual fund investor protection was the disclosure requirements of the Securities Act of 1933, Pub. L. No. 73-22, tit. I, 48 Stat. 74 (codified as amended at 15 U.S.C. \$§ 77a-77b (1976 \& Supp. V 1981)), and the Securities Exchange Act of 1934, Pub. L. No. 73-291, tit. I, 48 Stat. 881 (codified as amended at 15 U.S.C. $\S \S 78 \mathrm{a}-78 \mathrm{kk}$ (1976 \& Supp. V 1981)), but these did not prevent abuse. "Generally [the 1933 and 1934] Acts provide only for publicity. The record is clear that publicity alone is insufficient to eliminate malpractice in investment companies." H.R. REP. No. 2639, 76th Cong., 3d Sess. 10 (1940). See generally Randall, Fiduciary Duties of Investment Company Directors and Management Companies Under the Investment Company Act of 1940, 31 OKLA. L. Rev. 635, 636-37 (1978).

${ }^{20}$ See Brief for the SEC as Amicus Curiae at 10-11, Burks v. Lasker, 441 U.S. 471 (1979). See generally Investment Trusts and Investment Companies, H.R. Doc. No. 136, 77th Cong., 1st Sess., pt. 3, at 2485-2805 (1939); Note, supra note 7, at 725. Among the abuses leading to the enactment of the ICA were "discriminatory transactions that favored 
least forty percent of the directors of an investment company be "unaffiliated" with the adviser. ${ }^{21}$ The ICA also mandated that the "unaffiliated" directors approve the advisory fee contract between the fund and the adviser. ${ }^{22}$ The adoption of the ICA successfully eliminated the "flagrantly dishonest practices" which had plagued the industry. ${ }^{23}$

By the mid-1960's, however, the growth of the investment industry had created new problems. ${ }^{24}$ The unaffiliated directors appeared unable to prevent excessive advisory fees, ${ }^{25}$ and plaintiff

management," "inequitable pricing of shares," and "outright looting of assets." Id. at 725 n.41. For a list of some of the abuses intended to be eliminated by the ICA, see Investment Company Act of $1940 \S 1$ (b), 15 U.S.C. $\$ 80 a-1(b)$ (1976).

${ }^{21}$ Investment Company Act of 1940, Pub. L. No. 76-686, tit. I, § 10(a), 54 Stat. 789, 806 (codified as amended at 15 U.S.C. $\$ 80 \mathrm{a}-10$ (a) (1976)). "Unaffiliated" was defined to exclude officers, directors, employees, or owners of more than five percent of the voting securities of the adviser from the position of director of the investment company. See id. $\$ 2$ (a)(3) (codified at 15 U.S.C. $\$ 80 \mathrm{a}-2(\mathrm{a})(3)(1976)$ ).

${ }^{22} \mathrm{Id}$. $\$ 15$ (c) (codified as amended at 15 U.S.C. $\S 80 \mathrm{a}-15$ (c) (1976)). Additionally, the 1940 ICA required that the fund disclose certain information, such as investment strategies, to its shareholders, $i d$. at $\S 8(\mathrm{~b})$ (codified as amended at 15 U.S.C. $\S 80 \mathrm{a}-8(\mathrm{~b})$ (1976)) and that directors reapprove yearly any contract in effect for more than two years. Id. $\$ 15$ (a)(2) (codified as amended at 15 U.S.C. $\S 80 \mathrm{a}-15$ (a)(2)). The SEC was given the power to enforce the Act. Id. $\S 36$ (codified as amended at 15 U.S.C. $\$ 80 \mathrm{a}-35$ (1976)).

${ }^{23}$ Randall, supra note 19, at 638; see SEC REPORT, supra note 1, at 1, 5, 71.

24 In many instances, the economies of scale attributable to the growth of mutual funds were not shared with the investors of the fund. SENATE REPORT, supra note 13, at 6, reprinted in 1970 U.S. Code CoNG. \& AD. News at 4902; cf. Fox v. Reich \& Tang, Inc., 692 F.2d 250, 256-57 (2d Cir. 1982) (noting that management fees markedly exceeded fees charged by investment advisers to other institutional clients and the cost of management to those funds which manage themselves), cert. granted sub nom. Daily Income Fund v. Fox, 103 S. Ct. 1271 (1983).

${ }^{28}$ The 1966 SEC Report, which paved the way for the 1970 amendments to the ICA, concluded that the existing restraints on investment advisers' compensation were inadequate. This inadequacy resulted primarily from the lack of bargaining power on the part of the investment fund's independent directors vis-à-vis the investment adviser. SEC REPORT, supra note 1, at 131. Independent directors selected by the investment advisers are likely to be "friendly" directors who will not "rock the boat." See, e.g., Note, supra note 7, at 723. The independent directors usually have limited time for director duties, have no staff, and no external counsel, so they obtain most of their information about fund operations from the adviser. See SEC REPORT, supra note 1, at 130-31; Nutt, A Study of Mutual Fund Independent Directors, 120 U. PA. L. REv. 179, 220-22 (1971). In most cases, the directors have no feasible alternative to acceptance of the advisory contract, since rejection of the contract or termination of an existing contract leaves the fund without an adviser and at a serious risk. SEC REPORT, supra note 1, at 129, 131. There is also little possibility of shareholder-initiated opposition to the management of an investment fund, since shareholders are usually highly dispersed, with no one shareholder owning a large number of shares. Id. at 129-30. Thus:

The possibility of disrupting the fund's operations, the prospect of a bitter and expensive proxy contest, and the risk and uncertainty involved in replacing the entire fund management organization with a new and untested one, make termination of the existing advisory relationship a wholly unrealistic alternative in negotiations over advi- 
shareholders seeking to attack the fees in court were consistently defeated by the existing ICA standard that required them to prove that payment of the fees amounted to "corporate waste."26

In an attempt to control excessive advisory fees, Congress amended the ICA in 1970. Two principal changes pertinent to the demand requirement were made. ${ }^{27}$ First, Congress required that at least forty percent of an investment fund's directors be "disinterested,"28 rather than merely "unaffiliated."28 The disinterested directors were installed as "independent watchdogs"30 "to supply an independent check on management and to provide a means for the representation of shareholder interests in investment company

sory fees. Without such an alternative, advisory fees negotiated between advisers and the unaffiliated directors lack the essential element of arm's-length transactions and provide inadequate assurance that the fees bear a reasonable relationship to the price at which similar services could be obtained in a genuinely competitive market.

Id. at 131. See id. at 125-31 and Note, Mutual Funding, supra note 16, at 536-40, for a more detailed explanation of the conflicts of interest that were inherent in mutual fund management prior to the 1970 ICA amendments. For a survey of investment companies that shows the inequality of bargaining power between the directors and the adviser, see Nutt, supra, at $215-30$.

${ }^{28}$ See Fox v. Reich \& Tang, Inc., 692 F.2d 250, 259-60 (2d Cir. 1982), cert. granted sub nom. Daily Income Fund v. Fox, 103 S. Ct. 1271 (1983); SEC REPORT, supra note 1, at 13233. As of 1966, over 50 lawsuits had been instituted against mutual fund advisers. SEC REPORT, supra note 1, at 132. Only three cases were fully litigated. All three plaintiffs lost due to the difficulty of proving "corporate waste" under the old standard. Id. at 133-37; see Acampora v. Birkland, 220 F. Supp. 527 (D. Colo. 1963); Saxe v. Brady, 40 Del. Ch. 474, 184 A.2d 602 (1962). Proving corporate waste was "well nigh impossible." Fox v. Reich \& Tang, Inc., $692 \mathrm{~F} .2 \mathrm{~d}$ at 260 . Even as late as 1980 , after the fiduciary duty standard had been in effect for 10 years, there had never been a recovery on the merits in a suit alleging excessive advisory fees. Krasner v. Dreyfus Corp., 500 F. Supp. 36, 42 (S.D.N.Y. 1980).

27 Other amendments included changing the standard of liability for actions against an officer, director, or adviser of an investment company from "gross misconduct or gross abuse of trust," Investment Company Act of 1940, Pub. L. No. 76-686, tit. I, § 36, 54 Stat. 789, 841 (codified as amended at 15 U.S.C. $\$ 80-35$ (a) (1976)), to "breach of fiduciary duty involving personal misconduct." Investment Company Amendments Act of 1970, Pub. L. No. 91-547, $\S 20,84$ Stat. 1413, 1428-29 (codified as amended at 15 U.S.C. $\$ 80 \mathrm{a}-35$ (a) (1976)).

${ }^{28}$ Investment Company Amendments Act of 1970, Pub. L. No. 91-547, § 5(a), 84 Stat. 1413,1416 (codified at 15 U.S.C. $\$ 80 a-10(a)$ (1976)). "Interested" directors have a close relation with the adviser or its affiliates through "employment, stock ownership, substantial business or professional relationship, blood or marriage." Brief for the SEC as Amicus Curiae at 13, Burks v. Lasker, 441 U.S. 471 (1979); see Investment Company Act of 1940 § 2(a)(20), 15 U.S.C. § 80a-2(a)(20) (1976); see also SENATE REPORT, supra note 13, at 32-34, reprinted in 1970 U.S. Code Cong. \& AD. News at 4927.

29 Investment Company Act of 1940, Pub. L. No. 76-686, tit. I, § 10(a), 54 Stat. 789, 806 (codified as amended at 15 U.S.C. $\S 80 \mathrm{a}-10$ (a) (1976)). Directors are "unaffiliated" if they are not officers, directors, or employees of the adviser, and do not own or control more than five percent of the voting securities of the adviser. See id. 15 U.S.C. $\S 80 \mathrm{a}-2$ (a)(3) (1976).

so Burks v. Lasker, 441 U.S. 471, 484 (1979) (quoting Tannenbaum v. Zeller, 552 F.2d 402, 406 (2d Cir.), cert. denied, 434 U.S. 934 (1977)). 
affairs."31

Second, section 36 (b) was enacted to deal specifically with the problem of excessive advisory fees. ${ }^{32}$ Section $36(\mathrm{~b})$ expressly provides that the investment adviser owes a fiduciary duty to the investment company with respect to its own compensation. ${ }^{33}$ Congress was convinced that the "corporate waste" standard for judging advisory fees was "unduly restrictive."34 Congress also strengthened the directors' position by requiring that approval by the fund's directors of the compensation paid to the investment adviser "shall be given such consideration by the court as is deemed appropriate under all the circumstances." 35

Section 35(b)(3) provides that section 36(b) may be enforced through an action against the recipient of the allegedly excessive payments for actual damages resulting from the breach of fiduciary duty. ${ }^{38}$ Recovery is limited to the excess fees paid by the investment company during the one-year period prior to the initiation of

s1 Senate Report, supra note 13, at 32, reprinted in 1970 U.S. Code Cong. \& AD. NEws 4897, 4927. The "disinterested" directors are required to evaluate and approve the investment fund's advisory fee contracts. Investment Company Act of 1940 \& 15(c), 15 U.S.C. $\S 80 \mathrm{a}-15$ (c) (1976). The "disinterested" directors are also empowered to terminate an advisory fee contract with 60 days notice. Id. § 15(a)(3), 15 U.S.C. $\$ 80 \mathrm{a}-15(\mathrm{a})(3)$ (1976).

s2 See Senate Report, supra note 13, at 5-7, reprinted in 1970 U.S. Code Cong. \& AD. NEws 4897, 4901-03. Whether ICA regulation is necessary to deal with investment company advisory compensation has been questioned. Mutual fund investors do not seem concerned about potential cost savings on the part of the fund, as long as the investment performance of the fund is good. See SEC RePort, supra note 1, at 126. Mutual funds appear to be highly competitive; investors buy total returns, and the ability of investors to shop around and withdraw their money from funds on demand functions as an important control on the size of advisory fees. See E. Fama \& M. Jenson, Separation of Ownership and Control 22-23 (1982) (unpublished manuscript on file with The University of Chicago Law Review). Tacit collusion among investment advisers regarding the average fee is nonetheless a concern. Collusion is unlikely, however, given the large number of mutual funds and investment advisers controlling them. This comment accepts the statutory framework as a given.

s3 15 U.S.C. $\$ 80 a-35$ (b) (1976); see SENATE REPORT, supra note 13, at 6, reprinted in 1970 U.S. Code CoNG. \& AD. News at 4902.

${ }^{34}$ Id. at 5, reprinted in 1970 U.S. CoDE Cong. \& AD. News at 4901. The section may appear to "shift the responsibility for managing an investment company" from the directors to the courts, because it speaks in terms of legal standards. See Note, Direct not Derivative: Recovering Excessive Investment Advisor Fees in Mutual Funds, 71 GEo. L.J. 1595 (1983). Congress specifically indicated, however, that the purpose of the heightened standard was to "strengthen the ability of the unaffiliated directors to deal with [management fee] matters." Senate Report, supra note 13, at 7, reprinted in 1970 U.S. Code Cong. \& Ad. News at 4903.

35 Investment Company Amendments Act of 1970, Pub. L. No. 91-547, § 20, 84 Stat. $1413,1428-30$ (codified at 15 U.S.C. $\$ 80 \mathrm{a}-35(\mathrm{~b})(2)(1976)$ ).

s8 Investment Company Act of $1940 \S 36(\mathrm{~b})(3), 15$ U.S.C. $\S 80 \mathrm{a}-35(\mathrm{~b})(3)$ (1976); see supra note 4; see also Weiss v. Temporary Investment Fund, Inc. 692 F.2d 928, 933 (3d Cir. 1982). 
suit. ${ }^{37}$ Any recovery is paid into the investment fund's treasury. ${ }^{38}$

\section{B. The Current Debate}

The requirement of demand in section $36(\mathrm{~b})$ shareholder suits was unquestioned ${ }^{39}$ until the Supreme Court, in Burks v. Lasker, ${ }^{40}$ indicated in persuasive dicta that independent directors of investment companies could not terminate such suits under the "business judgment" rule. ${ }^{41}$ In Burks, the Supreme Court held that disinterested directors of an investment fund could terminate a suit brought under another section of the $\mathrm{ICA}^{42}$ if consistent with state law and the policy of the particular section of the ICA under which the suit was brought. ${ }^{43}$ But the Court indicated in dicta that a section 36(b) action could not be terminated, because "when Congress did intend to prevent board action from cutting off derivative suits, it said so expressly. Section $36(b), 15$ U.S.C. $§ 80 a-35(b)(2)$

37 Investment Company Act of $1940 \S 36$ (b)(3), 15 U.S.C. § 80a-35(b)(3) (1976).

ss Weiss v. Temporary Inv. Fund, 692 F.2d 928, 935 (3d Cir. 1982); Fox v. Reich \& Tang, Inc., 692 F.2d 250, 255 (2d Cir. 1982), cert. granted sub nom. Daily Income Fund v. Fox, 103 S. Ct. 1271 (1983).

3ง See, e.g., In re Kauffman Mut. Fund Actions, 479 F.2d 257 (1st Cir.), cert. denied, 414 U.S. 857 (1973) (unsuccessful pre-Burks challenge to the demand requirement in the context of excessive advisory fees).

40441 U.S. 471 (1979).

41 Id. at 484; see also Weiss v. Temporary Inv. Fund, 692 F.2d 928, 940 (3d Cir. 1982); Grossman v. Johnson, 674 F.2d 115, 121 (1st Cir.), cert. denied, 103 S. Ct. 85 (1982); Evangelist v. Fidelity Mgmt. \& Research Co., 554 F. Supp., 87, 92 (D. Mass. 1982); Note, supra note 7, at 733 n.113. For a fuller discussion of Burks, see infra notes 120-36 and accompanying text. The "business judgment" rule provides that

[i]f in the course of management, directors arrive at a decision, within the corporation's powers (intra vires) and their authority, for which there is a reasonable basis, and they act in good faith, as the result of their independent discretion and judgment, and uninfluenced by any consideration other than what they honestly believe to be the best interests of the corporation, a court will not interfere with internal management and substitute its judgment for that of the directors to enjoin or set aside the transaction or to surcharge the directors for any resulting loss.

H. Henn, B.J. Alexander, Handbook of the Law of Corporations and Other Business ENTERPRISES $\$ 242$, at 661 (3d ed. 1983) (footnotes omitted).

Director termination refers to the action of a court dismissing a derivative suit if, acting upon a shareholder's demand, the board of directors exercises its good-faith business judgment and refuses to sue or actively opposes the suit. Case Comment, supra note 1, at 604 n.18; see infra notes 120-37 and accompanying text. Although not necessary to the holding of Burks, the court's dicta have been accepted as a "strong signal," which "prudence" dictates must be obeyed. Weiss v. Temporary Inv. Fund, Inc., 692 F.2d at 939; see also Fox v. Reich \& Tang, Inc., 692 F.2d 250 (2d Cir. 1982), cert. granted sub nom. Daily Income Fund v. Fox, 103 S. Ct. 1271 (1983); Grossman v. Johnson, 674 F.2d at 121.

43 The plaintiffs in Burks brought suit under $\S 13(\mathrm{a})(3)$ and 36 of the unamended ICA, Investment Company Act of 1940, Pub. L. No. 76-768, tit. I, $\S \S 13(a)(3), 36,54$ Stat. 789, 811,841 (codified as amended at 15 U.S.C. $\$ \S 80 \mathrm{a}-13(\mathrm{a})(3),-35$ (a) (1976)). 441 U.S. at 473 .

434 U.S. at 480. 
... performs precisely this function for derivative suits charging breach of fiduciary duty with respect to adviser's fees." 44 Shareholder plaintiffs since Burks have therefore challenged the derivative nature of section 36(b) suits and asserted that, even if section 36(b) suits are derivative, the Burks "no-termination" rule renders futile any demand on the board of directors to pursue the suit. ${ }^{45}$ The Second Circuit has agreed with the shareholder plaintiffs. The other two circuits that have ruled on the question of demand have, however, disagreed with the shareholder plaintiffs, and required demand.

In Fox v. Reich \& Tang, Inc. ${ }^{48}$ the Second Circuit held that demand is not required in section $36(\mathrm{~b})$ shareholder suits because the investment fund itself has no cause of action under section 36(b). ${ }^{47}$ The court noted that there is no express authorization of a cause of action for the investment company in the language of section $36(\mathrm{~b}),{ }^{48}$ and argued that the "on behalf of" language in 36(b) did not imply a normal shareholder derivative action, but merely signified that the excess fees must be returned to the investment fund's treasury. ${ }^{49}$ The Second Circuit concluded that "[s]ince directors cannot cut off a suit and $\S 36(\mathrm{~b})$ does not authorize them to institute one, and because shareholder plaintiffs are necessarily challenging fees the directors evaluated and approved, ... the traditional reason for the demand requirement simply does not apply." A demand requirement in a section 36(b) action "would be an empty, unfruitful and dilatory exercise."

In Grossman v. Johnson ${ }^{52}$ and Weiss v. Temporary Invest-

44 Id. at 484 (footnote omitted).

15 Weiss v. Temporary Inv. Fund, Inc., 692 F.2d 928, 931-32 (3d Cir. 1982); Fox v. Reich \& Tang, Inc., 692 F.2d 250, 252-54 (2d Cir. 1982), cert. granted sub nom. Daily Income Fund v. Fox, 103 S. Ct. 1271 (1983); Grossman v. Johnson, 674 F.2d 115, 118-23 (1st Cir.), cert. denied, 103 S. Ct. 85 (1982).

st 692 F.2d 250 (2d Cir. 1982), cert. granted sub nom. Daily Income Fund v. Fox, 103 S. Ct. 1271 (1983).

47 Id. at 261. One commentator has adopted the Second Circuit's analysis. Note, supra note 34 , at 1600 . For further discussion of this Note, see infra notes 151, 173.

4s 692 F.2d at 255 .

19 Id. at 254-55.

so Id. at 261 (citations omitted).

s1 Id. at 262. The District Court for the Southern District of New York has also considered the $\S 36(\mathrm{~b})$ demand issue, with conflicting results. Compare Gartenberg v. Merrill Lynch Asset Mgmt., 91 F.R.D. 524 (S.D.N.Y. 1981) (demand required) and Markowitz v. Brody, 90 F.R.D. 542 (S.D.N.Y. 1981) (same) with Blatt v. Dean Witter Reynolds Intercapital, Inc., 528 F. Supp. 1152 (S.D.N.Y. 1982) (demand not a prerequisite to $\S 36($ b) suit) and Boyko v. Reserve Fund, 68 F.R.D. 692 (S.D.N.Y. 1975) (when at least one interested director is on the mutual fund board, futility of demand will be presumed).

${ }^{82} 674$ F.2d 115 (1st Cir.), cert. denied, 103 S. Ct. 85 (1982). 
ment Fund, Inc. ${ }^{53}$ however, the First and Third Circuits held that the shareholder action provided for in section $36(\mathrm{~b})$ was a derivative action. ${ }^{54}$ Both courts concluded on several grounds that the rule 23.1 demand requirement was entirely consistent with the section 36(b) statutory scheme. First, the Federal Rules of Civil Procedure presumptively apply to all cases brought under federal statutes unless Congress instructs otherwise. ${ }^{.5}$ Second, even assuming that Burks was correct, and that the independent directors of the mutual fund cannot terminate the section $36(\mathrm{~b})$ suit, demand would not necessarily be futile; if demand is required, the directors will still have an opportunity to study and remedy the advisory fee problem. ${ }^{5 B}$ Third, requiring demand furthers the purposes of the ICA by strengthening the independent management of investment funds by the independent directors. ${ }^{57}$

Resolution of the demand issue has "important ramifications for suits brought pursuant to $\S 36(\mathrm{~b}) .{ }^{\prime \prime 8}$ At stake is the authority of the board of directors to handle issues involving investment company advisory compensation, the ease with which a section 36(b) action may be brought and prosecuted by shareholders, and the efficient resolution of a section 36(b) action. As Grossman, Weiss, and Fox indicate, the crucial questions in the demand issue are whether a section $36(\mathrm{~b})$ suit is derivative and whether, if it is, demand is more than a futile exercise. The remainder of this comment analyzes these two questions.

\section{The Derivative Nature of Section 36(b) Actions}

The rule 23.1 demand requirement applies only to derivative suits brought by shareholders to enforce corporate rights. ${ }^{59}$ Section

s3 692 F.2d 928 (3d Cir. 1982).

B4 The court in Grossman held that the statute provided a direct cause of action for an investment company, because the language "on behalf of" normally implies "a derivative action that the company could itself bring." $674 \mathrm{~F} .2 \mathrm{~d}$ at 120 . The court in Weiss, although not disagreeing with the Grossman rationale, went on to hold that the § 36 (b) shareholder suit was derivative because a cause of action for the company can be inferred from the statute. $692 \mathrm{~F} .2 \mathrm{~d}$ at 934 . In Weiss, the court relied on the test announced in Cort v. Ash, 422 U.S. 66 (1975), which looks primarily to legislative history to determine the propriety of implied causes of action, and found that the legislative history of $\S 36(b)$ suggested no intent to deprive the company of a direct remedy. 692 F.2d at 935 . For a more detailed discussion of the implied cause of action in $\S 36(\mathrm{~b})$, see infra notes 60-71 and accompanying text.

ss Weiss, 692 F.2d at 936; Grossman, 674 F.2d at 122-23.

se Weiss, 692 F.2d at 938-42; Grossman, 674 F.2d at 121.

s7 Weiss, 692 F.2d at 937, 942; Grossman, 674 F.2d at 122.

ss Fox v. Reich \& Tang, Inc., 692 F.2d 250, 252 (2d Cir. 1982), cert. granted sub nom. Daily Income Fund v. Fox, 103 S. Ct. 1271 (1983).

so Rule 23.1 provides, in relevant part: 
36 (b) gives an express cause of action to "shareholders" of an investment company "on behalf of such company," but no express cause of action to the company itself. It is unclear whether investment companies have an implied cause of action under section $36(\mathrm{~b})$. It is also unclear whether the explicit section $36(\mathrm{~b})$ cause of action is a derivative one based on the rights of the investment company or an independent one granted directly to shareholders.

\section{A. The Investment Company's Implied Cause of Action}

The rule 23.1 demand requirement "applies only when a corporation or association has 'failed to enforce a right which may properly be asserted by it." "\$o The investment company itself has no express cause of action under section $36(\mathrm{~b})$; the language of the section only provides actions for the SEC and for shareholders. ${ }^{81} \mathrm{~A}$ cause of action for the investment company may, however, be implied by section $36(\mathrm{~b})$.

"The central inquiry" in determining whether to infer a private cause of action requires asking "whether Congress intended to create, either expressly or impliedly, a private cause of action."

In a derivative action brought by one or more shareholders or members to enforce a right of a corporation or of an unincorporated association, the corporation or association having failed to enforce a right which may properly be asserted by it, the complaint shall be verified. . . . The complaint shall also allege with particularity the efforts, if any, made by the plaintiff to obtain the action he desires from the directors or comparable authority, and, if necessary, from the shareholders or members, and the reasons for his failure to obtain the action or for not making the effort. . . . The action shall not be dismissed or compromised without the approval of the court, and notice of the proposed dismissal or compromise shall be given to shareholders or members in such manner as the court directs.

FEd. R. Crv. P. 23.1.

Bo Fox v. Reich \& Tang, Inc., 692 F.2d 250, 253 (2d Cir. 1982) (quoting Fed. R. Crv. P. 23.1), cert. granted sub nom. Daily Income Fund v. Fox, 103 S. Ct. 1271 (1983). If an investment company has no cause of action and cannot sue under $\S 36(\mathrm{~b})$, the shareholder action provided under $\S 36(\mathrm{~b})$ is not derivative, and demand upon the company's board of directors will not be required. See id. at 254 .

B1 Investment Company Act of 1940 § 36(b), 15 U.S.C. § 80a-35(b) (1976).

62 Touche Ross \& Co. v. Redington, 442 U.S. 560, 575 (1979); see Middlesex County Sewerage Auth. v. National Sea Clammers Ass'n, 453 U.S. 1, 13 (1981); Universities Research Ass'n, Inc. v. Coutu, 450 U.S. 754, 770 (1981); Transamerica Mortgage Advisors v. Lewis, 444 U.S. 11, 15 (1979). See generally Stewart \& Sunstein, Public Programs and Private Rights, 95 HaRv. L. REv. 1193, 1302-07 (1982); Sunstein, Section 1983 and the Private Enforcement of Federal Law, 49 U. CHI. L. REv. 394, 413 (1982). Although given a rather narrow reading by the Supreme Court in the cases cited above, the factors identified by the Court in Cort v. Ash, 422 U.S. 66 (1975), as relevant to the inquiry into whether an implied right of action exists, which include the status of the plaintiff as a special beneficiary of the statute, the legislative intent, the applicability of private remedies within the statutory context, and the remedies available through state law, are still relevant to that inquiry insofar 
Private rights of action are not to be lightly inferred, because unintended private enforcement may create a remedy "that is significantly broader than the remedy that Congress chose to provide," thereby disturbing a balance of interests set by Congress. ${ }^{84}$

Inferring a private cause of action for the investment company under section 36(b) does not disturb Congress's remedial plan. Section 36(b) was not designed to be exclusively enforced by the government; the statute authorizes private actions by shareholders. ${ }^{65}$ Because private actions by the company itself and private actions by the shareholders both result in the return of excess fees to the company treasury, ${ }^{68}$ and both utilize the same enforcement mechanism, a suit against the investment advisors, ${ }^{67}$ an implied cause of action for the company would have little effect on the remedial balance established by Congress in section $36(\mathrm{~b}) .^{8 \mathrm{~B}}$

Under the 1940 ICA, courts consistently found an implied cause of action whereby an investment company could recover excessive compensation under section $36^{69}$ The legislative history of the 1970 ICA amendments indicates no congressional dissatisfaction with the prevailing judicial finding of a private cause of action. ${ }^{20}$ Since Congress clearly intended private enforcement to occur and, at least tacitly approved, because it did not eliminate, the existing implied cause of action for the investment company, a private cause of action for investment companies should continue to

as they help determine congressional intent. Touche Ross, 442 U.S. at 575; Universities Research, 450 U.S. at 770.

ss Touche Ross \& Co. v. Redington, 442 U.S. 560, 574 (1979). Implied causes of action can also result in overdeterrence and excessive enforcement costs. See Stewart \& Sunstein, supra note 62, at 1303 .

4 See Middlesex County Sewerage Auth. v. National Sea Clammers Ass'n, 453 U. S. 1, 14-15 (1981); Universities Research Ass'n, Inc. v. Coutu, 450 U.S. 754, 773-77 (1981); Touche Ross \& Co. v. Redington, 442 U.S. 560, 569 (1979); Sunstein, supra note 62, at 413-14.

os Investment Company Act of $1940 \S 36(\mathrm{~b}), 15$ U.S.C. $\$ 80 a-35(b)$ (1976); see supra note 4.

68 See supra note 38 and accompanying text. The Supreme Court "consistently has found that Congress intended to create a cause of action "where the language of the statute explicitly confer[s] a right directly on a class of persons that include[s] the plaintiff in the case." "Universities Research Ass'n, Inc. v. Coutu, 450 U.S. 754, 771-772 (1981) (quoting Cannon v. University of Chicago, 441 U.S. 677, 690 n.13 (1979)).

${ }^{87}$ Investment Company Act of $1940 \S 36$ (b), 15 U.S.C. $\$ 80 a-35$ (b) (1976).

68 The court in Grossman v. Johnson, 674 F.2d (1st Cir.), cert. denied, 103 S. Ct. 85 (1982), also noted that it would be incredible if "a new and independent board of directors, intent on recovering excess fees from the investment adviser, would be precluded from suing under $\S 36(\mathrm{~b})$." Id. at 120 (footnote omitted).

6o See, e.g., Tanzer v. Huffines, 314 F. Supp. 189, 195 (D. Del. 1970); Acampora v. Birkland, 220 F. Supp. 527, 532 (D. Colo. 1963).

7o See infra notes 85-90 and accompanying text. 


\section{B. The Derivative Nature of the Express Shareholder Action}

Even after one has concluded that the investment company has an implied cause of action under section $36(\mathrm{~b})$, the question still remains whether the express cause of action granted to shareholders by section $36(\mathrm{~b})$ is derivative of, or independent from, the corporation's cause of action. The inquiry begins with the language of the statute which refers to a shareholder's right to sue "on behalf of such company." 72 In corporation law, a shareholder suit "on behalf of such company" usually refers to a derivative suit that the company itself could bring. ${ }^{73}$ Although the "on behalf of" language

71 "When Congress acts in a statutory context in which an implied private remedy has been recognized by the courts . . . the question is whether Congress intended to preserve the existing remedy." Merrill Lynch, Pierce, Fenner \& Smith, Inc. v. Curran, 456 U.S. 353, 378-79 (1982). "[T]he fact that a comprehensive reexamination and significant amendment of [a statute] left intact the statutory provisions under which the federal courts had implied a cause of action is itself evidence that Congress affirmatively intended to preserve that remedy." Id. at 381-82 (footnote omitted).

${ }_{72}$ Investment Company Act of 1940, $\$ 36(\mathrm{~b}), 15$ U.S.C. $\$ 80 \mathrm{a}-35$ (b) (1976).

73 The "on behalf of" terminology in the corporation context is uniformly used in federal statutes. For example, 28 U.S.C. $\S 1401$ (1976) and 28 U.S.C. $\S 1695$ (1976) are both entitled "Stockholder's Derivative Action." Section 1401 is a venue statute that provides that "any civil action by a stockholder on behalf of his corporation may be prosecuted in any judicial district where the corporation might have sued the same defendants." (emphasis added). Section 1695 provides that "process in a stockholder's action in behalf of his corporation may be served upon such corporation in any district where it is organized . . . to do business . . ." (emphasis added). Section 16(b) of the Securities Exchange Act of 1934, 15 U.S.C. $\S 78 \mathrm{p}(\mathrm{b})$ (1976), and $\S 17$ (b) of the Public Utility Holding Company Act of 1935 , 15 U.S.C. $₹ 79 q(b)(1976)$, both provide that, in certain situations, shareholders may sue "in the name and on the behalf of" their company to recover profits from the purchase and sale of securities by interested persons. These actions are clearly derivative. One might argue that Congress left the "in the name of" language out of $\S 36(\mathrm{~b})$ because it intended to create an independent shareholder action. Yet, given the uniform use of the "on behalf of" terminology to refer to derivative suits, the omission of the accessory clause is not determinative of the section's meaning.

Most states also have statutes establishing procedures for shareholder derivative suits. Although most of these statutes provide that a derivative action shall be brought "in the right of" the corporation to procure a judgment for the corporation, e.g., N.Y. Bus. CoRP. LAW § 626 (McKinney 1963), some statutes also use the "on behalf of" language. New York provides that "[i]f the action on behalf of the corporation" is successful, the plaintiff can recover attorney's fees. Id. $\$ 626$ (e) (emphasis added). California provides that if there is a strong prima facie case in favor of a "claim asserted on behalf of the corporation," a plaintiff need not allege that he was a shareholder at the time of the transaction complained of. CaL. CoRP. Code $\S 800$ (b)(1) (West 1977) (emphasis added). Cases and commentators have also emphasized that "[a] derivative suit is brought by shareholders to enforce a claim on behalf of the corporation." Burks v. Lasker, 441 U.S. 471, 477 (1979) (emphasis added); see also Smith v. Sperling, 354 U.S. 91, 99 (1957) (Frankfurter, J., dissenting) (in a derivative suit a "the stockholder sues . . . in the right and on behalf of the corporation") (emphasis 
can be read as an effort to appoint shareholders as "private attorneys general" to help enforce section 36(b) for the benefit of the investment companies, ${ }^{74}$ there is nothing in the legislative history of 36(b) to support such a reading. Absent any special rationale identified by Congress, courts should give to the term "on behalf of" its usual interpretation. ${ }^{75}$

Apart from the language of the statute, a section 36(b) shareholder suit has all the characteristics of a derivative suit. Typically, derivative suits are based on the rights of the corporation, ${ }^{78}$ seek to redress injuries to the corporation, ${ }^{77}$ and direct all recovery to the corporation's treasury and not to the individual shareholders. ${ }^{78}$ Section $36(\mathrm{~b})$ suits share all of these characteristics. First, in section 36(b) suits, the fiduciary duty imposed on the adviser is owed to the company and is not a right of the individual shareholders. ${ }^{79}$ Second, the $36(\mathrm{~b})$ action redresses a corporate injury; the

added); Lewis v. S.L. \& E., Inc., 629 F.2d 764, 768 n.10 (2d Cir. 1980) (shareholder may "assert claims on behalf of the corporation in a derivative action") (emphasis added); Shell v. Hensley, 430 F.2d 819, 824 (5th Cir. 1970) (Rule 10b-5 action "may be invoked on behalf of a corporation in a shareholder's derivative suit") (emphasis added); Rose Hall, Ltd. v. Chase Manhattan Overseas Banking Corp., 494 F. Supp. 1139, 1151 (D. Del. 1980) ("in a derivative action, the plaintiff stockholder sues on behalf of the corporation") (emphasis added); Clark v. Lomas \& Nettleton Fin. Corp., 79 F.R.D. 641,646 (N.D. Tex. 1978) ("shareholder's derivative suit . . . is a procedure by which shareholders of a corporation can assert a right of action on behalf of the corporation") (emphasis added), rev'd on other grounds, 625 F.2d 49 (5th Cir. 1980), cert. denied, 450 U.S. 1029 (1981); Comment, The Demand and Standing Requirements in Stockholder Derivative Actions, 44 U. Crr. L. Rev. 168,168 (1976) (derivative suit is brought "on behalf of the corporation to redress the harm") (emphasis added).

24 See Fox v. Reich \& Tang, Inc., 692 F.2d 250, 255 (2d Cir. 1982), cert. granted sub nom. Daily Income Fund v. Fox, 103 S. Ct. 1271 (1983).

75 2A SANDS, SutherLand's Statutory Construction \$ 46.01, at 48-50 (1975).

76 In a derivative suit, the "rights sought to be vindicated are those of the corporation." Annot., 48 A.L.R.3D 595, 599 n.1 (1973); see 3B J. Moore \& J. Kennedy, MoOrE's Federal Practice fi 23.1.16[1], at 23.1-47 (2d ed. 1948).

77 Stevens v. Lowder, 643 F.2d 1078, 1080 (5th Cir. 1981); see Vincel v. White Motor Corp., 521 F.2d 1113, 1118 (2d Cir. 1975); Tankersly v. Albright, 80 F.R.D. 441, 444 (N.D. Ill. 1978); Abrams v. Mayflower Investors, Inc., 62 F.R.D. 361, 369 (N.D. Ill. 1974); Von Brimer v. Whirlpool Corp., 367 F. Supp. 740, 744 (N.D. Cal. 1973).

78 "An action to redress injuries to a corporation cannot be maintained by a shareholder in his own name, but must be brought in the name of the corporation [derivatively]." That the shareholder suffers a decline in assets is "insufficient direct harm to give the shareholder standing to sue in his own right." Clark v. Lomas \& Nettleton Fin. Corp., 79 F.R.D. 641, 646 (N.D. Tex. 1978), rev'd on other grounds, 625 F.2d 49 (5th Cir. 1980), cert. denied, 450 U.S. 1029 (1981); see Ross v. Bernhard, 396 U.S. 531, 538 (1970); Smith v. Sperling, 354 U.S. 91, 99 (1957) (Frankfurter, J., dissenting); 7A C. Wright \& A. Miller, Federal PracTICE AND PROCEDURE § 1821, at 294-95 (1972).

79 Weiss v. Temporary Inv. Fund, 692 F.2d 928, 935 (3d Cir. 1982); see Senate REport, supra note 13, at 6, reprinted in 1970 U.S. Code ConG. \& AD. NEws at 4902 ("the investment adviser should be a fiduciary of the fund"). But see id. at 2, reprinted in 1970 U.S. 
payment of excessive fees to the investment adviser injures the investment company as a whole and not only the shareholders as individuals. ${ }^{80}$ Third, any recovery in a section $36(\mathrm{~b})$ suit reverts to the investment fund, not to the shareholder plaintiff. ${ }^{81}$

The "contemporary legal context"82 and the legislative history of the 1970 ICA amendments both indicate that the section 36(b) shareholder action was intended to be derivative. First, the fact that Congress did not expressly grant a private cause of action to the company, and thus expressly create a shareholder derivative suit, ${ }^{83}$ despite the derivative characteristics of section $36(\mathrm{~b})$ shareholder suits, may stem less from a congressional intent to restrict derivative suits than from the legal realities at the time the statute was drafted. At the time of the 1970 ICA amendments, all suits challenging excessive advisory fees had been brought by shareholders. ${ }^{84}$ Congress may have used the language "on behalf of" expecting that shareholders alone would bring section 36(b) suits. Such an expectation would have corresponded to the typical form of prior suits, but it does not necessarily deprive the shareholder suit of its derivative character, or of the procedures attendant upon derivative suits, such as demand.

Second, prior to the 1970 amendments, section 36(b) shareholder suits against investment advisers for excessive fees were

Code Cong. \& AD. NEws at 4898 (investment adviser has a fiduciary duty "with respect to mutual fund shareholders"). Even before the ICA amendments, there existed some case law holding that the investment adviser was "a fiduciary of the fund he advises." Mutual Fund Amendments: Hearings on H.R. 11995 Before the Subcomm. on Commerce and Finance of the House Comm. on Interstate and Foreign Commerce, 91st Cong., 1st Sess. 189 (1969) (SEC Memo) [hereinafter cited as House Hearings]; see Brown v. Bullock, 294 F.2d 415, 421 (2d Cir. 1961); SEC v. Insurance Sec., Inc., 254 F.2d 642, 650 (9th Cir.), cert. denied, 358 U.S. 823 (1958). Today, cases and commentators continue to refer to the adviser's fiduciary duty as being owed to the fund. See Grossman v. Johnson, 674 F.2d 115, 118 (1st Cir.) (plaintiff's suit alleged breach of fiduciary duty "to the Fund"), cert. denied, $103 \mathrm{~S}$. Ct. 85 (1982); Note, Mutual Fund Advisory Fees and the New Standard of Fiduciary Duty-Interpreting the 1970 Mutual Fund Act, 56 CoRnecl L. REv. 627, 627 (1971) (adviser has a fiduciary duty to the fund with regard to receipt of management fees).

so Weiss v. Temporary Inv. Fund, 692 F.2d 928, 935 (3d Cir. 1982).

si Id.

${ }^{82}$ See Merrill Lynch, Pierce, Fenner \& Smith, Inc. v. Curran, 456 U.S. 353, 381 (1982).

83 See Fox v. Reich \& Tang, Inc., 692 F.2d 250, 256 (2d Cir. 1982), cert. granted sub nom. Daily Income Fund v. Fox, 103 S. Ct. 1271 (1983).

84 Between 1959 and 1966, over 50 suits were instituted against advisers alleging excessive advisory fees. SEC REPORT, supra note 1, at 132. These suits were all derivative actions brought by shareholders. See id. at 132-33. The fact that the investment company directors are unlikely to initiate a $\S 36(\mathrm{~b})$ action does not mean that they are incapable of objectively evaluating the merits of a $\S 36$ (b) claim once demand is made by a shareholder. See generally infra notes 150-186 and accompanying text. 
strictly derivative, ${ }^{85}$ since they were based on the corporation's right to recovery for "corporate waste." ${ }^{\mathrm{B8}}$ The legislative history of the 1970 ICA amendments indicates that the purpose of the new section 36(b) was to "ameliorate the 'unduly restrictive' standard of 'corporate waste' which shareholders had been required to prove in implied derivative actions for excessive fees under the original § 36." ${ }^{\text {"87 }}$ Congressional concern focused extensively on the fiduciary duty of the advisers and the standards by which advisers' fees were to be judged without once focusing on the derivative nature of the pre-section $36(\mathrm{~b})$ actions. ${ }^{88}$ The clear implication is that in enacting the 1970 ICA amendments Congress did not disapprove of the form of the remedy (a shareholder derivative suit), but merely sought to change the standard of care from "corporate waste" to "fiduciary duty". ${ }^{89}$ Since Congress gave no indication that section 36(b) shareholder actions were not intended to be derivative, Congress can be presumed to have incorporated the derivative nature of the pre-1970 shareholder suits into the section $36(\mathrm{~b})$ action. ${ }^{30}$

ss Prior to the 1970 amendments, a private cause of action was consistently recognized allowing a shareholder to sue derivatively under $\$ 36$. See Moses v. Burgin, 445 F.2d 369, 373 (1st Cir. 1971); Randall, supra note 19, at 649. Some of these suits challenged excessive advisory compensation. See Tanzer v. Huffines, 314 F. Supp. 189, 192 (D. Del. 1970); Acampora v. Birkland, 220 F. Supp. 527, 532 (D. Colo. 1963). State court challenges to advisory fees were also brought as shareholder derivative actions. See, e.g., Saxe v. Brady, 40 Del. Ch. 474, 476, 184 A.2d 602, 604 (1962).

s6 Senate Report, supra note 13, at 5, reprinted in 1970 U.S. Code Cong. \& AD. News at 4901; see supra note 26 and accompanying text.

${ }^{87}$ Note, Mutual Fund Independent Directors: Putting a Leash on the Watchdogs, 47 FordhaM L. Rev. 568, 575 n.57 (1979); see also Senate RkPORT, supra note 13, at 5-7, reprinted in 1970 U.S. Code CoNG. \& AD. Nzws at 4901-03. Congress was concerned that the pre-amendment ICA did not provide adequate mechanisms "by which the fairness of management contracts could be tested in court." Id. at 5, reprinted in 1970 U.S. Cope ConG. \& AD. News at 4901.

section 36(b)'s "sole purpose [was] to specify the fiduciary duty of the investment adviser with respect to compensation, and provide a mechanism for court enforcement of this duty." Senate Report, supra note 13, at 6, reprinted in 1970 U.S. Code Cong. \& AD. News at 4902 . Cases support the conclusion that the motivation behind the implementation of $\S 36(\mathrm{~b})$ was to ease the difficult burden faced by shareholders trying to prove that their advisory fees violated common law prohibitions against corporate waste. See, e.g., Weiss v. Temporary Inv. Fund, 692 F.2d 928, 933 (3d Cir. 1982); Fox v. Reich \& Tang, Inc., 692 F.2d 250, 261 (2d Cir. 1982), cert. granted sub nom. Daily Income Fund v. Fox, 103 S. Ct. 1271 (1983); see infra text accompanying note 90.

so The Second Circuit itself said that "[r]ecognizing that shareholder plaintiffs had difficulty sustaining their burdens, Congress changed only the standard of duty." Fox v. Reich \& Tang, Inc., 692 F.2d 250, 260 (2d Cir. 1982) (emphasis added), cert. granted sub nom. Daily Income Fund v. Fox, 103 S. Ct. 1271 (1983).

90 A number of courts and commentators have relied on this presumption. The Supreme Court has stated that $\S 36$ (b) shareholder suits are derivative suits charging breach of fiduciary duty with respect to advisory fees. Burks v. Lasker, 441 U.S. 471, 484 (1979); see 
The section $36(\mathrm{~b})$ shareholder action is therefore derivative. The investment company has an implied cause of action under section $36(\mathrm{~b})$, and the language, characteristics, and legislative history of the section 36(b) shareholder action indicate a congressional intent that that action be derivative.

\section{The Functions of Demand in Section 36(b) Actions}

Federal Rule of Civil Procedure 23.1 instructs shareholders that prior to bringing any derivative action they must either make a demand on the board of directors of the corporation in an attempt "to obtain the action [they] desire from the directors" or give an excuse for failure to make this demand. ${ }^{91}$ Plaintiffs in section 36(b) actions argue that even if the section 36(b) suit is a derivative one, the rule 23.1 demand requirement is inconsistent with the legislative purposes and policy underlying section $36(\mathrm{~b})$. Therefore, they argue, the demand requirement should be automatically excused in section $36(\mathrm{~b})$ actions as a conclusive presumption of law. ${ }^{92}$ These arguments are ultimately unpersuasive. The importance of conformity with the Federal Rules of Civil Procedure and the legislative history and purposes behind the adoption of section $36(\mathrm{~b})$, namely, the strengthening of independent directors and the need for efficiency in the disposition, including settlement, of section 36(b) suits, all lead to the conclusion that demand should be required.

Markowitz v. Brody, 90 F.R.D. 542, 557 n.12 (S.D.N.Y. 1981) ("Shareholder suits under Section 36(b) care unfailingly described by the courts and commentators as 'derivative actions.' "). See also Untermeyer v. Fidelity Daily Income Trust, 580 F.2d 22, 23 (1st Cir. 1978); Tarlov v. Paine Webber Cashfund, 559 F. Supp. 429, 431-32 (D. Conn. 1983) (plaintiff brought a "shareholder derivative suit" under § 36(b)); Evangelist v. Fidelity Mgmt. \& Research Co., 554 F. Supp. 87, 88 (D. Mass. 1982); Gartenberg v. Merrill Lynch Asset Mgmt., Inc., 91 F.R.D. 524, 525 (S.D.N.Y. 1981); Krasner v. Dreyfus Corp., 500 F. Supp. 36, 37 (S.D.N.Y. 1980) ("shareholder derivative actions brought on behalf of" the fund under 36(b)); Galfand v. Chestnutt Corp., 402 F. Supp. 1318, 1321, 1325 (S.D.N.Y. 1975); Comment, supra note 73, at 177 n.64; Note, supra note 7, at 728 ("Congress, in section 36(b), authorized shareholders to bring a derivative action against the adviser"); cf. supra note 71 . In Grossman v. Johnson, 674 F.2d 115 (1st Cir. 1982), the plaintiff apparently brought his $\S 36$ (b) suit as a derivative action, $i d$. at 117; this is also true of the plaintiff in Markowitz v. Brody, 90 F.R.D. 542, at 546 (S.D.N.Y. 1981).

92 FED. R. Civ. P. 23.1.

${ }^{82}$ See Weiss v. Temporary Inv. Fund, 692 F.2d 928, 938 (3d Cir. 1982); Grossman v. Johnson, 674 F.2d 115, 121 (1st Cir.), cert. denied, 103 S. Ct. 85 (1982); Markowitz v. Brody, 90 F.R.D. 542, 554 (S.D.N.Y. 1981). 


\section{A. Promoting Conformity with the Federal Rules}

Unless Congress indicates otherwise, "a subsequently enacted statute should be . . . construed . . . to harmonize with the Federal Rules if . . . at all feasible." 36 (b) "alludes to the continued operation of the demand requirement." 94 During congressional hearings on the 1970 amendments, SEC Chairman Hamer Budge stated: "there are adequate safeguards under the Federal Rules of Civil Procedures [sic] and under this bill to prevent unjustified shareholder litigation." "9s Later Chairman Budge specifically cited "Rule 23 [sic] FRCP" as a safeguard against frivolous or harassing lawsuits. ${ }^{96}$ The presumption that rule 23.1 applies to "any civil suit brought in a federal district court" ${ }^{\prime \prime 2}$ is not contested by any statement in the legislative history of section $36(\mathrm{~b})$ and therefore should apply to suits under that statute.

In general, the rule 23.1 demand requirement for derivative suits is adhered to strictly. ${ }^{98}$ While the trial court does have the discretion to excuse demand, such excuse will be granted only on a strict showing of "futility." "Demand will be excused only if it is clear from the circumstances "that the demand upon the directors would meet rejection by them." 100 Demand is required "if there is

-s Federal Rule of Civil Procedure 1 states that the Federal Rules "govern the procedure in the United States district courts in all suits of a civil nature." In Califano v. Yamasaki, 442 U.S. 682, 700 (1979), the Supreme Court held that a Federal Rule of Civil Procedure is always to be followed "[i]n the absence of a direct expression by Congress of its intent to depart from the . . . Rules." For example, in United States v. Gustin-Bacon Div. Certain-teed Prod. Corp., 426 F.2d 539 (10th Cir.), cert. denied, 400 U.S. 832 (1970), rule 8(a) (permitting notice pleading) was held to apply to a discrimination action brought under $\S 707$ (a) of the Civil Rights Act of 1964, 42 U.S.C. $\S 2000 \mathrm{e}-6$ (a) (1976), even though that section provided that, in bringing an action, the United States Attorney General should set "forth facts pertaining to such pattern or practice" of discrimination. The court held that it would follow rule $8(a)$ since Congress had not clearly indicated that the rule was to be preempted.

9 Weiss v. Temporary Inv. Fund, 692 F.2d 928, 938 (3d Cir. 1982).

os House Hearings, supra note 79, at 201 (answers to questions proposed by Rep. Hastings Keith in his letter of Nov. 12, 1969 to SEC Chairman Budge).

${ }^{28}$ Id. at 860 n.12 (statement of Hamer Budge, Chairman, SEC). Prior to 1966, the federal civil procedure rules pertaining to derivative suits were found in rule $23.2 \mathrm{~J}$. Moore \& J. KENNEDY, supra note 76, II 23.1.01[1].

${ }^{97}$ Weiss v. Temporary Inv. Fund, 692 F.2d 928, 936 (3d Cir. 1982).

ss "[T]he demand requirement of Rule 23.1 should be rigorously enforced . . .." Cramer v. General Tel. \& Elecs. Corp., 582 F.2d 259, 275 (3d Cir. 1978), cert. denied, 439 U.S. 1129 (1979); see also Weiss v. Temporary Inv. Fund, 692 F.2d 928, 940-42 (3d Cir. 1982); Lewis v. Curtis, 671 F.2d 779, 784 (3d Cir. 1982); Gartenberg v. Merrill Lynch Asset Mgmt., Inc., 91 F.R.D. 524, 526 (S.D.N.Y. 1981); Comment, supra note 73, at 173.

2" J. MOORE \& J. KenNEDY, supra note 76, I 23.1.19, at 23.1-83 to -93 .

${ }^{100}$ Id. at 23.1-89 (footnote omitted); see Greenspun v. Del E. Webb Corp., 634 F.2d 
any chance that the directors may take remedial action in response to the shareholders' complaint."101

Certain factual patterns have been held to support an allegation that the directors are unable to consider demand objectively. ${ }^{102}$ First, demand may be excused as futile where the directors are actually controlled by the alleged wrongdoers. ${ }^{103}$ Second, a conflict of interest on the part of the directors with respect to the transaction at issue will excuse demand, but only if the facts indicate that the interests of the directors are clearly adverse to those of the shareholders. ${ }^{104}$ Third, the fact that a majority of the board of directors actively participated in the transaction attacked will excuse demand, ${ }^{105}$ but the "majority view is that mere passive approval of an allegedly injurious corporate transaction, absent selfinterest or bias by the majority of the board, is insufficient." ${ }^{106} \mathrm{Fi}-$

1204, 1209-10 (9th Cir. 1980); Clark v. Lomas \& Nettleton Fin. Corp., 625 F.2d 49, 53 (5th Cir. 1980), cert. denied, 450 U.S. 1029 (1981); Galef v. Alexander, 615 F.2d 51, 59 (2d Cir. 1980); Note, supra note 7, at 729 n.79; Annot., 99 A.L.R.3D 1034, 1036 (1980).

${ }^{101}$ Comment, supra note 73, at 173 (footnote omitted). One commentator has written that "[g]iven the advantages of the demand requirement and the ease of compliance, the shareholders should be required to make demand in almost every case (footnote omitted)." Id.

${ }^{102}$ Rule 23.1 provides that the derivative plaintiff must "allege with particularity" any reasons for failing to make demand. Fed. R. Civ. P. 23.1. See 3 B J. Moore \& J. KenNedy, supra note 76 , I 23.1 .19 , at 23.1-80 to -82 . See generally Comment, supra note 73 , at 173-82, for a discussion on particular standards for excusal of demand.

${ }^{10 s}$ Comment, supra note 73, at 173. The usual situation is where a wrongdoer owns a substantial percentage of stock in the complaining shareholder's corporation and thus has control over the election of directors or management of the business. See, e.g., Cathedral Estates, Inc. v. Taft Realty Corp., 228 F.2d 85 (2d Cir. 1955); Maxwell v. Enterprise Wall Paper Mfg. Co., 47 F. Supp. 999, 1001 (E.D. Pa.), rev'd on other grounds, 131 F.2d 400 (3d Cir. 1942). But see De Hass v. Empire Petroleum Co., 286 F. Supp. 809 (D. Colo. 1968), aff'd, 435 F.2d 1223 (10th Cir. 1970); see also Greenspun v. Del E. Webb Corp., 634 F.2d 1204, 1209 (9th Cir. 1980); In re Kauffman Mut. Fund Actions, 479 F.2d 257, 264 (1st Cir.), cert. denied, 414 U.S. 857 (1973).

104 See Jones v. Equitable Life Assurance Soc'y, 409 F. Supp. 370, 372-73 (S.D.N.Y. 1975); Comment, supra note 73, at 174-75. In Cathedral Estates, Inc. v. Taft Realty Corp., 228 F.2d 85 (2d Cir. 1955), demand was excused because the defendant directors of the plaintiff's corporation were the sole owners of the defendant corporation in the case. See also Delaware \& H. Co. v. Albany \& S.R.R., 213 U.S. 435, 443, 450 (1909).

${ }^{103}$ Comment, supra note 73, at 176; see In re Kauffman Mut. Fund Actions, 479 F.2d 257, 264 (1st Cir.), cert. denied, 414 U.S. 857 (1973). Demand is excused when a majority of the directors have engaged in fraud or self-dealing. See Parish v. Maryland \& Va. Milk Producers Ass'n, 250 Md. 24, 84, 242 A.2d 512, 545, (1968), cert. denied, 404 U.S. 940 (1971). In Lewis v. Curtis, 671 F.2d 779, 784-87 (3d Cir. 1982), demand was excused because the directors who had approved of the alleged wrongful transaction were also active participants in a plan to prevent any attempts to obtain control of the corporation in order to entrench themselves in their positions.

${ }^{108}$ In re Kauffman Mut. Fund Actions, 479 F.2d 257, 264-65 (1st Cir.), cert. denied, 414 U.S. 857 (1973); accord Weiss v. Temporary Inv. Fund, 692 F.2d 928, 943 (3d Cir. 1982); 
nally, unequivocal director opposition to the suit will excuse demand. ${ }^{107}$

In accordance with the general standard, demand is normally excused in section 36(b) suits if a majority of the board of directors is "interested" within the meaning of ICA section 2(a)(19). ${ }^{108}$ However, in a section 36 (b) suit where a majority of the directors are disinterested, the general standard indicates that the mere fact that these directors have necessarily approved the investment company's advisory compensation schedule is insufficient to excuse demand. Courts have generally held that demand is not excused in cases involving investment companies where the wrongs complained of concerned the company's investment adviser, and where a minority of the directors were affiliated with the adviser and allegedly participated in the wrongful acts while the majority of directors, who were unaffiliated with the adviser, merely ratified them. ${ }^{109}$ Any other result presumes that the independent directors deliberately conspired with the affiliated directors to approve the acts that are the subject of the shareholders' complaint. ${ }^{110}$ The directors may, however, conceive of their approval as an error in bus-

Greenspun v. Del E. Webb Corp., 634 F.2d 1204, 1210 (9th Cir. 1980); Galef v. Alexander, 615 F.2d 51, 60 (2d Cir. 1980); Heit v. Baird, 567 F.2d 1157, 1160-61 (1st Cir. 1977); Brody v. Chemical Bank, 517 F.2d 932, 934 (2d Cir. 1975). Contra Liboff v. Wolfson, 437 F.2d 121 (5th Cir. 1971). See generally Comment, supra note 73 , at 178-80, which explains that demand should still be required in these situations for three reasons. First, acquiescence in the transaction absent self-interest should not "create an irrebuttable presumption that directors would not entertain a claim for relief (footnote omitted)." Demand may refocus directors' fiduciary duties, and give them an opportunity to correct harm that they may have caused. Indeed, they have incentives to take such action in order to avoid a subsequent shareholder suit for the previous wrongdoing. Second, the demand requirement would otherwise be seriously undermined, since directors participate in and probably approve of all major transactions of the corporation. Third, by not requiring demand sham pleading is encouraged, as shareholders will name all the directors as defendants in order to bootstrap themselves into court.

${ }^{107}$ Comment, supra note 73, at 180-81. See Nussbacher v. Conitinental Ill. Nat'l Bank \& Trust Co., 518 F.2d 873, 879 (7th Cir. 1975), where, prior to plaintiff's demand, the directors had refused suit in an almost identical action and had adopted an uncompromising position that they would not initiate an action.

${ }^{108} 15$ U.S.C. $\$ 80 \mathrm{a}-2(\mathrm{a})(19)$ (1976), construed in Untermeyer v. Fidelity Daily Income Trust, 580 F.2d 22, 23-24 (1st Cir. 1978); Markowitz v. Brody, 90 F.R.D. 542, 556 (S.D.N.Y. 1981).

${ }^{100}$ Annot., 99 A.L.R.3D 1034, 1036 (1980). In re Kauffman Mutual Fund Actions, 479 F.2d 257 (1st Cir.), cert. denied, 414 U.S. 857 (1973), was such a case. There, the court expressly rejected the suggestion that the disinterested directors of a mutual fund were incapable of fairly considering demand after earlier approving of an adviser-fund transaction. Id. at 266-67. "To the extent that [the independent directors] are 'watchdogs' they should be given the opportunity [to respond to demand], not deprived of it." Id. at 267.

${ }^{110}$ In re Kauffman Mut. Fund Actions, 479 F.2d 257, 265 (1st Cir.), cert. denied, 414 U.S. 857 (1973). 
iness judgment which they would correct " if . . . asked to do so." "111 Requiring demand therefore would give them the opportunity to exercise that statutorily mandated judgment. ${ }^{112}$

\section{B. Strengthening Independent Directors}

"The cornerstone of the ICA's efforts to control conflicts of interest within mutual funds is the requirement that at least $40 \%$ of a fund's board be composed of independent outside directors." 113 One of Congress' main purposes in enacting the 1970 ICA amendments was to strengthen the role of the disinterested directors and place them "in the role of 'independent watchdogs' . . . who would 'furnish an independent check upon the management' of investment companies."114 Section 36(b) could be read as granting to independent directors only the initial responsibility for negotiating and approving the advisory fee contract, while giving courts the sole responsibility for evaluating advisory fees once a section $36(\mathrm{~b})$ suit has been brought. ${ }^{115}$ However, this interpretation conflicts with the congressional intent to give the disinterested directors "primary responsibility" for supplying an "independent check on management" and "for looking after the interests of the funds' shareholders." "116

The legislative history of section 36 (b) does not specifically address the independent directors' responsibilities when faced with demand. It does indicate that the responsibility placed on the disinterested directors by section $36(\mathrm{~b})$ is broad and far-reaching, extending into the area of the management fees paid by the com-

${ }^{121}$ Id. (quoting Bartlett v. New York, N.H., H.R.R., 221 Mass. 530, 536, 109 N.E. 452, 455 (1915)).

${ }^{112}$ See generally Lerman v. ITB Mgmt. Corp., 58 F.R.D. 153, 158 (D. Mass. 1973); Senate Report, supra note 13, at 32, reprinted in 1970 U.S. Code Cong. \& Ad. NEwS at 4927. Critics of the disinterested director provisions argue that the same conflicts of interest still exist after the $1970 \mathrm{ICA}$ amendments, in that directors still cannot take the ultimate step of terminating the advisory contract, that failure of the directors to evaluate the advisory contract under their duty is hard to detect, and that directors need only look a little bit harder to find congenial disinterested directors. Randall, supra note 19, at 663-64.

${ }_{113}$ Burks v. Lasker, 441 U.S. 471, 482 (1979); see Investment Company Act of 1940 § 10(a), 15 U.S.C. $\$ 80 a-10$ (a) (1976).

${ }_{114}$ Burks v. Lasker, 441 U.S. 471, 484 (1979) (quoting Tannebaum v. Zeller, 552 F.2d 402, 406 (2d Cir. 1977)); see SENATE REPoRT, supra note 13, at 7, reprinted in 1970 U.S. Code Cong. \& AD. NEwS at 4903. The directors act as a check on advisory fees due to their statutory duty of evaluating and approving advisory fees and their authority to terminate investment adviser contracts.

${ }^{125}$ See Case Comment, supra note 1, at 626-29.

${ }_{116}$ Burks v. Lasker, 441 U. S. 471, 484-85 (1979); see In re Kauffman Mut. Fund Actions, 479 F.2d 257, 266 (1st Cir.), cert. denied, 414 U.S. 857 (1973). 
pany. ${ }^{117}$ The legislative history makes it clear that section $36(\mathrm{~b})$

is not intended to authorize a court to substitute its business judgment for that of the mutual fund's board of directors in the area of management fees. . . .

... A responsible determination regarding the management fee by directors including a majority of the disinterested directors is not to be ignored.

... [T] $]$ his section is designed to strengthen the ability of the unaffiliated directors to deal with [management fee] matters [and provide a means whereby the court can enforce the adviser's fiduciary duty]. ${ }^{118}$

Directors are generally intelligent and have considerable resources of "'persuasion and publicity" "which they can bring to bear on the adviser. ${ }^{119}$ It would be anomalous to excuse demand automatically and remove all authority from the disinterested directors with respect to section $36(\mathrm{~b})$ suits.

The analysis of demand in the context of the statutory purpose of section 36(b) is not altered by the explicit dicta of Burks $v$. Lasker, ${ }^{120}$ which assert that independent directors of investment companies may not terminate a section 36(b) shareholder action under the "business judgment" rule. ${ }^{121}$ In arriving at this conclusion, the Supreme Court relied on the language of section $36(\mathrm{~b})(2)$ that "approval by the board of directors of such investment company of such compensation [to the adviser] . . . shall be given such consideration . . . as is deemed appropriate," tive history of section $36(\mathrm{~b})$, which provides that "the ultimate responsibility for the decision ... whether the fiduciary duty has

117 Senate Report, supra note 13, at 6-7, reprinted in 1970 U.S. Code Cong. \& Ad. News at 4902-03.

218 Id.

118 Randall, supra note 19, at 664 (quoting Comment, Mutual Funds and Independent Directors: Can Moses Lead to Better Business Judgment, 1972 Duke L.J. 429, 462 n.195). Even though independent directors may be unable to terminate the advisory contract, they have other recourses available to them. They can always take their case to the shareholders or generate adverse publicity. Thus, "[f] ew advisers will continue a practice if the directors raise well-reasoned objections against it." Nutt, supra note 25 , at 266.

120441 U.S. 471 (1979).

121 Id. at 484.

${ }_{122}$ Investment Company Act of $1940 \S 36(\mathrm{~b})(2), 15$ U.S.C. $\S 80 \mathrm{a}-35(\mathrm{~b})(2)$ (1976) (cited in Burks v. Lasker, 441 U.S. 471, 484 (1979)); see Weiss v. Temporary Inv. Fund, 692 F.2d 928, 940 (3d Cir. 1982); Grossman v. Johnson, 674 F.2d 115, 121 (1st Cir.), cert. denied, 103 S. Ct. 85 (1982); Evangelist v. Fidelity Mgmt. \& Research Co., 554 F. Supp. 87, 92 (D. Mass. 1982); Note, supra note 7, at 733 n.113. 
been breached rests with the court."123

If termination is permitted, the issue of this comment is easily resolved, for demand is a necessary antecedent to termination. Even if termination is not permitted in section $36(\mathrm{~b})$ actions, ${ }^{124}$ however, that conclusion does not necessarily indicate that independent directors cannot respond objectively to demand or that demand should be automatically excused. First, Burks expressly rejected the argument that mutual fund directors are presumed to be too self-interested to terminate section 36(b) suits; if Congress thought them too self-interested, it would not have entrusted those directors with the "critical functions" granted to them under the ICA. ${ }^{25}$ Since directors are not presumed to be self-interested, a presumption in favor of excusing demand seems inappropriate.

Second, section $36(\mathrm{~b})(2)$ indicates that a court should give some consideration to "determination by the independent directors as to the propriety of the advisory compensation."126 Section 36(b)(2) suggests judicial deference toward a thoroughly considered rejection of demand by the independent directors in a section 36(b) action. "[T] he court may ultimately rely on the board's rejection of the claim to support its own refusal to grant any relief" at the summary judgment stage. ${ }^{127}$ Thus, section $36(\mathrm{~b})(2)$ can be thought of as providing a special "business judgment" rule for section $36(\mathrm{~b})$ suits with directors bearing the burden of proving their

123 Senate Report, supra note 13, at 6, reprinted in 1970 U.S. Code Cong. \& AD. News at 4903 . It would be anomalous to place ultimate responsibility on the judiciary for determining whether disinterested directors were successful in preventing excessive fees, while giving the judiciary a passive role once a corporate litigation committee decided to terminate a $\$ 36$ (b) suit. Note, supra note 7, at 618 . Congress was concerned specifically with the recurring problem of mutual fund advisory fees, and it wanted to create a "mechanism by which the fairness of management contracts could be tested in court." SENATE REPORT, supra note 13, at 5, 7 reprinted in 1970 U.S. CoDE CoNG. \& AD. NEws 4897, 4901, 4903.

${ }^{124}$ Commentators have debated whether director termination of $\$ 36(\mathrm{~b})$ shareholder actions should be permitted. Compare Case Comment, supra note 1, at 619-26 (directors should not be permitted to terminate, since termination would neutralize $\S 36(\mathrm{~b})$ suits) with Note, supra note 7, at 733-43 (termination should be permitted, and courts should review only the reasonableness of the board's investigation and its basis for termination). The business judgment termination rule functions as a shareholder protection device by preventing derivative suits where the expected costs of the suit are greater than the expected benefits. See Joy v. North, 692 F.2d 880, 887, 890 (2d Cir. 1982), cert. denied, 108 S. Ct. 1498 (1983); cf. Note, supra note 1, at 619-25 (If abused by directors, the termination rule neutralizes the value of a derivative suit.). In any event, the Burks dicta that directors cannot terminate a $\S$ 36(b) suit is inconsistent with the emphasis of the rest of that opinion on the "watchdog" role to be played by the independent directors. See Burks, 441 U.S. at 481-85.

${ }^{125}$ Burks, 441 U.S. at 481-82; see also Weiss v. Temporary Inv. Fund, 692 F.2d 928, 939 (3d Cir. 1982); cf. Burks, 441 U.S. at 485 n.15.

${ }^{128}$ Investment Company Act of $1940 \S 36(\mathrm{~b})(2), 15$ U.S.C. $\S 80 \mathrm{a}-35(\mathrm{~b})(2)$ (1976).

127 Markowitz v. Brody, 90 F.R.D. 542, 562 (S.D.N.Y. 1981). 
good faith and the reasonableness of their judgment in rejecting demand, and a court retaining the authority to review the merits of the directors' judgment. ${ }^{128}$ This interpretation of section $36(\mathrm{~b})(2)$ gives the directors great incentive to investigate an excessive advisory fee claim objectively once a demand is made by a shareholder. Moreover, under a demand requirement, neither party is deprived of any right afforded it by section 36(b); directors may still seek to influence the affairs of the corporation through their response to demand, and the courts will have the final say on the resolution of advisory fee issues after demand is made.

"While the demand requirement and the termination of derivative suits under the business judgment rule are "inextricably linked,"128 because both "stem from the principle that primary responsibility for corporate management lies with the board of directors," 130 the two rules involve two separate inquiries, import different legal standards and have different legal consequences. ${ }^{131}$ The primary purpose of the demand requirement is to exhaust intracorporate remedies prior to bringing suit, thus giving the directors of the corporation the first opportunity to remedy the problem; ${ }^{132}$ the consequence of demand is merely a determination of who will pursue the claim, the corporation or the shareholder. ${ }^{133}$ In general, only "futility" excuses demand.134 The primary purpose of the "business judgment" termination rule, by contrast, is to permit

${ }^{128}$ In the normal termination situation, where demand is made and refused by a board of directors, the shareholder has the burden of proving that the directors' decision was wrongful in order for the derivative suit to proceed, Joy v. North, 692 F.2d 880, 887 (2d Cir. 1982) cert. denied, 103 S. Ct. 1498 (1983); see Auerbach v. Bennett, 47 N.Y.2d 619, 630-31, 393 N.E.2d 994, 1000, 419 N.Y.S.2d 920, 926-27 (1979); the court will not review the merits of the directors' determination, but only whether the directors' investigation was independent, reasonable, and in good faith. Id. at 631,393 N.E.2d at 1001,419 N.Y.S. $2 d$ at 927. Under $\S 36(b)(2)$, however, the directors obviously have the burden of proving the validity of their determination, because a court need not give any weight to that determination. In deciding whether the directors have satisfied their burden, the court might look at data from discovery, and at the committee's investigation and reasoning. See Joy, 692 F.2d at 892. The legislative history indicates that Congress intended that a court consider the merits of whether the investment adviser has committed a breach of fiduciary duty. See SENATB REPorT, supra note 13, at 6, reprinted in 1970 U.S. CODE CoNG. \& AD. NEwS at 4902-03; Nutt, supra note 25, at 266; Randall, supra note 19, at 664; see also supra note 123 and accompanying text.

138 Cramer v. General Tel. \& Elecs. Corp., 582 F.2d 259, 274 (3d Cir. 1978), cert. denied, 439 U.S. 1129 (1979).

1so Evangelist v. Fidelity Mgmt. \& Research Co., 554 F. Supp. 87, 90 (D. Mass. 1982).

131 Id.

132 See infra notes 138-145 and accompanying text.

${ }_{13 s}$ Evangelist v. Fidelity Mgmt. \& Research Co., 554 F. Supp. 87, 90 (D. Mass. 1982);

see infra notes 138-145 and accompanying text.

234 See supra notes 98-101 and accompanying text. 
competent directors, rather than ill-equipped courts, to decide the business-related issue of whether a corporate action should be brought. ${ }^{135}$ The consequence of this rule is drastic, for a decision by the directors to terminate the suit bars the claim entirely. Because of its different consequences, the demand requirement is more strictly enforced than the termination rule; while only futility excuses demand, courts allow shareholders to sue in the face of a board's decision to terminate whenever the shareholders can show wrongfulness on the part of the directors. ${ }^{136}$ Since derivative suits are important weapons in remedying corporate abuses, it may be desirable in some situations to prevent directors from precluding suit, while at the same time requiring demand to give the directors the chance to remedy the situation efficiently. ${ }^{137}$ Demand without power of termination leaves the latter determination, as section 36 (b) suggests, in the hands of the judiciary, while giving directors full exercise of the powers section $36(\mathrm{~b})$ grants them. Thus, the Supreme Court's statement in Burks that termination of section 36(b) suits is not permitted does not preclude the propriety of requiring demand in the section $36(\mathrm{~b})$ context.

295 See H. HenN \& B.J. AleXANDER, supra note 41 , $\$ 242$, at 661 .

136 Joy v. North, 692 F.2d 880, 887 (2d Cir. 1982), cert. denied, 103 S. Ct. 1498 (1983); Zapata Corp. v. Maldonado, 430 A.2d 779, 784, 787 (Del. 1981); see Galef v. Alexander, 615 F.2d 51, 60 (2d Cir. 1980); supra notes 102-107 and accompanying text.

${ }^{137}$ While the demand requirement should be vigorously enforced, the business judgment of the directors should not be totally insulated from judicial review. Cramer v. General Tel. \& Elecs. Corp., 582 F.2d 259, 275 (3d Cir. 1978), cert. denied, 439 U.S. 1129 (1979). The court in Weiss v. Temporary Inv. Fund, 692 F.2d 928 (3d Cir. 1982), states that:

It is not inconsistent for a court to employ a strict standard with respect to the excusal of demand, but then to refuse to accept a decision by the same board of directors to seek termination of the same action. . . . As some decisions have emphasized, the focus at the demand stage should be on the issue of whether the corporation may take over the suit and either prosecute it or adopt other internal corrective measures, and not on the later question of whether a decision not to sue should be respected by the court. At the demand stage the possibility should not be foreclosed that a demand will induce the board to consider issues and crystallize policies which otherwise might not be given attention (e.g., new accounting controls, revised corporate policy statements or even a change in personnel or remuneration). The demand rule can have efficacy even where the board ultimately rejects the action and the court ultimately permits the plaintiff to sue.

Id. at 941-42. See Principles of Corporate Governance and Structure: Restatement and Recommendations $\S 7.02$, at 270-71 (Tent. Draft No. 1, 1982); see also Heit v. Baird, 567 F.2d 1157, 1162 n.6 (1st Cir. 1977); Note, supra note 73, at 172 ("Once demand on the directors has been made and rejected, the exhaustion requirement of rule 23.1 is met and the rule does not bar a derivative action.") (footnote omitted). 


\section{Promoting Efficiency in Shareholder Actions}

1. General Functions of Demand. The rule 23.1 demand requirement serves several important functions in the disposition of derivative claims. First, demand allows the board of directors to exercise its normal function as the decision-maker for the corporation by bringing information to its attention ${ }^{138}$ and by giving it the first opportunity to take control of a suit brought on the corporation's behalf. ${ }^{139}$ It is usually more efficient for the directors of the corporation to pursue the claim and remedy the wrong. ${ }^{140}$ Therefore, "a shareholder's suit is to be resorted to as a last alternative, and ... the corporation is [to be] given every possibility to sue in its own name."141

Demand also promotes the settlement of disputes by forcing the shareholder to exhaust all possible intracorporate avenues for redressing his grievances before litigating a derivative suit. ${ }^{142}$ De-

138 See Brief of the SEC as Amicus Curiae at 15, Burks v. Lasker, 441 U.S. 471 (1979).

139 See Weiss v. Temporary Inv. Fund, 692 F.2d 928, 940-41 (3d Cir. 1982); Heit v. Baird, 567 F.2d 1157, 1162 n.6 (1st Cir. 1977); Markowitz v. Brody, 90 F.R.D. 542, 560 (S.D.N.Y. 1981); Note, Demand on Directors and Shareholders as a Prerequisite to a Derivative Suit, 73 HARv. L. REv. 746, 748 (1960). The demand requirement "furthers a principle basic to corporate organization, that the management of the corporation be entrusted to its board of directors." Note, supra note 73, at 171; see Evangelist v. Fidelity Mgmt. \& Research Co., 554 F. Supp. 87, 90 (D. Mass. 1982).

140 The corporation is a more efficient prosecutor of a derivative claim for several reasons. First, the corporation possesses more information than the shareholders and thus can "pursue the action more efficiently." Abrams v. Mayflower Investors, Inc., 62 F.R.D. 361, 369 (N.D. Ill. 1974). Second, the corporation will generally have greater financial ability with which to prosecute the suit. Id. Third, the corporate officers and directors owe a fiduciary duty to act in the interests of the corporation in the maintenance of the action, whereas a shareholder has no such obligation. Id.

141 J. MOORE \& J. KENNEDY, supra note 76, I 23.1.19, at 23.1-82; see id. II 23.1.15[4]; C. Wright \& A. Miller, supra note 78, $\S 1831$, at 374-75. "The purpose of requiring . . . demand ... before bringing suit is related to the concept that a shareholder derivative action is a device to be used only when it is clear that the corporation will not act to redress the alleged injury to itself." Lerman v. ITB Mgmt. Corp., 58 F.R.D. 153, 157 (D. Mass. 1973) (citation omitted).

142 This was the original reason for imposing a demand requirement in derivative suits. In the seminal case of Hawes v. Oakland, 104 U.S. 450 (1882), the Supreme Court required that a shareholder, before he could institute a derivative suit, must "show to the satisfaction of the court that he has exhausted all the means within his reach to obtain, within the corporation itself, the redress of his grievances, or action in conformity with his wishes." Id. at $460-461$. This policy actually benefits all parties concerned, because

[t]he dissident shareholder is provided with an opportunity to achieve his goal without incurring the expense of litigation; the directors of the corporation are allowed to occupy their status as managers of the corporation's affairs; the corporation is left to clean its own house, free from judicial entanglements; and the courts are relieved of the burden of prematurely resolving intracorporate disputes.

Mills v. Esmark, Inc., 91 F.R.D. 70, 72 (N.D. Ill. 1981); see also Weiss v. Temporary Inv. 
mand gives the directors an opportunity to take remedial actions that may make the litigation unnecessary. ${ }^{143}$ Demand thereby "promote[s] judicial economy."144

Third, the demand requirement inhibits "strike suits" brought by shareholders solely for settlement value. ${ }^{145}$ Strike suits are groundless nuisance suits brought "not to benefit but to extort a settlement from the corporation, which wants to avoid the expense and disruption of litigation." 146 Where a potential recovery in a "settled" strike suit involves a large fee for the attorney and a relatively small recovery for the corporation, a derivative action "may be harmful to shareholders because the costs offset the recovery."147 Demand discourages plaintiffs and their attorneys from bringing strike suits. The possibility that, upon receiving demand, the board of directors might take over and prosecute the suit itself, settle with the defendants, or terminate the suit inhibits strike

Fund, 692 F.2d 928, 940-41 (3d Cir. 1982) (plaintiffs must exhaust intracorporate remedies); Galef v. Alexander, 615 F.2d 51, 59 (2d Cir. 1980) (same); Heit v. Baird, 567 F.2d 1157, 1162 n.6 (1st Cir. 1977) (plaintiffs must give corporation opportunity to put house in order); Markowitz v. Brody, 90 F.R.D. 542, 560-61 (S.D.N.Y. 1981) (plaintiffs must exhaust intracorporate remedies and foster amicable resolution of differences); Note, supra note 73, at 171 (demand requirement prevents courts from interfering with internal affairs of corporation until plaintiff exhausts intracorporate remedies).

${ }^{163}$ The demand requirement "gives management the opportunity to pursue alternative remedies and to avoid unnecessary litigation." Weiss v. Temporary Inv. Fund, 692 F.2d 928, 942 (3d Cir. 1982) (citation omitted).

${ }^{144}$ C. WRIGHT \& A. MiLLER, supra note 78, § 1832, at 384 (1972). "The grievance may be resolvable without litigation, thus easing the burden of the courts." See Note, supra note 73, at 172 (footnote omitted); see also Cramer v. General Tel. \& Elecs. Corp., 582 F.2d 259, 275 (3d Cir. 1978), cert. denied, 439 U.S. 1129 (1979); Markowitz v. Brody, 90 F.R.D. 542, 560-61 (S.D.N.Y. 1981); Note, supra note 139, at 749 (all discussing policies underlying demand requirement). Between 1940 and 1981, the number of cases filed annually in the federal district courts rose from 35,000 to 180,000. Burger, Isn't There a Better Way? Annual Report on State of the Judiciary, 68 A.B.A. J. 274, 275 (1982).

345 See Surowitz v. Hilton Hotels Corp., 383 U.S. 363, 371 (1966); Cramer v. General Tel. \& Elecs. Corp., 582 F.2d 259, 275 (3d Cir. 1978), cert. denied, 439 U.S. 1129 (1979); Markowitz v. Brody, 90 F.R.D. 542, 561 (S.D.N.Y. 1981); Galfand v. Chestnutt Corp., 402 F. Supp. 1318, 1331 (S.D.N.Y. 1975) aff'd, 573 F.2d 1290 (2d Cir. 1977); C. WRIGHT \& A. Muler, supra note 78, § 1831, at 382; Note, supra note 73, at 172, Annot., 48 A.L.R.3D 595, 607 (1973).

${ }^{168}$ Dent, The Power of Directors to Terminate Shareholder Litigation: The Death of the Derivative Suit?, 75 Nw. U.L. REv. 96, 137 (1980) (footnote omitted). The term "strike suits" is used in this comment to refer not only to suits without any merit, but also to suits where the costs to the corporation in pursuing the claim are greater than the potential benefits. Derivative actions are, of course, useful insofar as they act as a legitimate check on management. See Zapata Corp. v. Maldonado, 430 A.2d 779, 786 (Del. 1981).

147 Joy v. North, 692 F.2d 880, 887 (2d Cir. 1982), cert. denied, 103 S. Ct. 1498 (1983); see Zapata Corp. v. Maldonado, 430 A.2d 779, 786-87 (Del. 1981); Scott, Corporation Law and the New Institutional Economics 23-24 (April 25, 1983) (unpublished manuscript) (available in the offices of The University of Chicago Law Review). 
suits. ${ }^{148}$

Finally, demand serves several other minor practical functions, ${ }^{149}$ such as notifying the directors of the alleged cause of action and informing the shareholders of directors' refusal to prosecute it. ${ }^{150}$

2. Application of the Demand Requirement to Section 36(b) Suits. In determining whether the rule 23.1 demand requirement should be enforced in section $36(\mathrm{~b})$ suits, the essential inquiry is whether, if termination is not permitted, the functions served by demand in the normal derivative suit are furthered by requiring demand in a section 36 (b) suit.

a. Increasing Directors' Options. Requiring demand in section 36(b) suits serves the function of allowing the directors to act as managers of the company by giving them the first opportunity to remedy the dispute. Even though they cannot terminate a section 36(b) suit, the directors have a number of options available to them upon receiving demand. First, they may take over the suit and prosecute it themselves; ${ }^{151}$ should the directors fail to prosecute in good faith, the shareholders can sue the directors for breach of fiduciary duty under section $36(\mathrm{a}) .{ }^{152}$ Second, the directors can pursue informal remedies, such as settlement to recover

168 See Markowitz v. Brody, 90 F.R.D. 542, 562 (S.D.N.Y. 1981); Dent, supra note 146, at 138-39; Note, supra note 139 , at 749 .

140 See Markowitz v. Brody, 90 F.R.D. 542, 560 (S.D.N.Y. 1981). The demand requirement also usually serves to set the stage for "determining whether the shareholder has standing to maintain a derivative action." Id. Since $\S 36(\mathrm{~b})$ directors cannot terminate, demand does not set the stage for a determination of shareholder standing: the shareholders are granted standing by the statute. But note that the demand requirement itself does not serve the function of determining standing; whether the directors should be permitted to terminate under the business judgment doctrine is an inquiry totally separate from the demand requirement. See Cramer v. General Tel. \& Elecs. Corp., 582 F.2d 259, 275 (3d Cir. 1978), cert. denied, 439 U.S. 1129 (1979); Zapata Corp. v. Maldonado, 430 A.2d 779, 787 (Del. 1981); Note, supra note 7, at 729; Note, supra note 139, at 759; Note, supra note 73, at 191-200.

180 For an enumeration of these functions, see Lerman v. ITB Mgmt. Corp., 58 F.R.D. 153, 157-58 (D. Mass. 1973); Note, supra note 139, at 748-49; Note, supra note 73, at 171.

${ }^{181}$ Weiss v. Temporary Inv. Fund, 692 F.2d 928, 941 (3d Cir. 1982). Even if the company does not take over the suit, it might nonetheless accede to the complainant's views, a factor to which a court might give considerable weight under $\$ 36(b)(2)$. See Grossman v. Johnson, 674 F.2d 115, 121 (1st Cir.), cert. denied, 103 S. Ct. 85 (1982). It has been argued that directors are inhibited from bringing suit under $\S 36(\mathrm{~b})$ because of their potential liability under $\S 36(a)$ if the fees they negotiated are found to be unreasonable. Note, supra note 34 , at 1616 . However, $\S 36$ (a) insures that the directors will objectively consider a $\$ 36$ (b) shareholder's demand, since they could be subject to liability under $\S 36$ (a) for a bad faith rejection of demand.

${ }^{132}$ See supra note 31 and accompanying text. 
the excessive fees or renegotiation of the advisory fee schedule. ${ }^{153}$ Finally, the directors can refuse demand, in which case the shareholder is still entitled to bring the section 36(b) action, since termination is not permitted. This refusal, however, will allow the directors to express their views on the merits of the action, which views may be given significant weight by the courts under section $36(b)(2){ }^{154}$

b. Promoting Settlements. Requiring demand in section 36(b) actions furthers the policy of exhausting intracorporate remedies prior to bringing derivative suits. The directors may take remedial action, such as a settlement, that renders litigation unnecessary. Settlements of shareholder derivative litigation are favored by the courts in order to avoid the litigation costs" ${ }^{155}$ of these "notoriously difficult and unpredictable" suits. ${ }^{156}$

All parties involved in a meritorious section $36(\mathrm{~b})$ action have incentive to reach a legitimate settlement in order to avoid the expense and disruption of complicated litigation. ${ }^{157}$ Because no termination is permitted in section $36(\mathrm{~b})$ suits, the demand requirement is likely to promote the chances for a settlement, since demand provides the only opportunity for directors and advisers "to avert a lawsuit through internal corrective measures."158

${ }^{153}$ See infra notes $156-168$ and accompanying text.

154 See supra note 127 and accompanying text; see also Grossman v. Johnson, 674 F.2d 115, 121 (1st Cir.), cert. denied, 103 S. Ct. 85 (1982). One might argue that many of the actions open to an investment company after receivng demand could be taken by the investment company after shareholders brought suit even if demand were not required. This, however, is the case in any derivative suit; nonetheless, demand is nearly always required. A formal demand requirement increases the potential for successful pre-litigation resolution of issues before a complaint is ever filed in federal court.

IBS J. MOORE \& J. KENNEDY, supra note 76, I 23.1.24[2], at 23.1-132, 23.1-137; see Krasner v. Dreyfus Corp., 90 F.R.D. 665, 673 (S.D.N.Y. 1981).

${ }^{\text {IsB }}$ Schimmel v. Goldman, 57 F.R.D. 481, 487 (S.D.N.Y. 1973) (quoting Zerkle v. Cleveland-Cliffs Iron Co., 52 F.R.D. 151, 159 (S.D.N.Y. 1971)).

${ }^{15 z}$ Because it provides an opportunity to avoid litigation costs, settlement will often be the best resolution of a meritorious $\S 36(\mathrm{~b})$ claim. In successful derivative litigation, the plaintiff's attorney's fees are paid by the corporation on whose behalf the action is taken. Shlensky v. Dorsey, 574 F.2d 131, 149 (3d Cir. 1978). In the settlement of a derivative claim, the court limits awards of attorney's fees to the "reasonable value of services benefitting . . . the claimant," City of Detroit v. Grinnell Corp., 495 F.2d 448, 470 (2d Cir. 1974) (quoting Lindy Bros. Builders, Inc. v. American Radiator \& Standard Sanitary Corp., 487 F.2d 161, 167 (3d Cir. 1973)) (footnote omitted). Thus, an attorney receives smaller fees in the settlement of a suit than he would through the successful litigation of it. Both the adviser and the investment company can benefit from the settlement: the investment company benefits by taking a larger portion of a smaller recovery (it has to pay less to plaintiff's attorney), and the adviser benefits by negotiating a smaller recovery than he might be forced to pay through litigation.

${ }^{158}$ Weiss v. Temporary Inv. Fund, 692 F.2d 928, 942 (3d Cir. 1982). Prior to the imple- 
In general, rule 23.1 requires judicial approval of settlements of derivative suits entered into between plaintiff shareholders and defendants in order to prevent private, collusive settlements in which the plaintiff shareholder and his attorney get the sum paid by the directors in the settlement and the corporation gets nothing. ${ }^{159}$ Judicial approval is awarded only to settlements that are "fair, reasonable, and adequate." 160 After approval, the settlement has res judicata effect. ${ }^{101}$ Since the directors of a corporation are entitled to settle a derivative complaint out of court without judicial approval, ${ }^{162}$ however, it is possible that requiring demand in section 36(b) suits could lead to "sham" settlements between the investment company directors and the company's adviser that deprive the plaintiff of his remedy.

Sham settlements are unlikely. When the investment company settles out of court it "acts at its [own] peril."163 The out-of-court settlement

fails to compromise or dismiss the derivative action . . . [and] also leaves the derivative plaintiff free 'to challenge the settlement, either by pursuing the original action and attempting to overthrow the settlement or by bringing a new action against the directors in which the settlement itself is the gravamen of the complaint." ${ }^{\text {'164 }}$

mentation of $\$ 36(b)$, most suits alleging excessive advisory fees were settled, even though plaintiffs had a very difficult task proving "corporate waste." SEC REPORT, supra note 1, at 132-33; see Fox v. Reich \& Tang, Inc., 692 F.2d 250, 260 (2d Cir. 1982), cert. granted sub nom. Daily Income Fund v. Fox, 103 S. Ct. 1271 (1983). Under the current fiduciary-duty standard, settlements of meritorious $\S 36(\mathrm{~b})$ suits should be even more likely, because of the plaintiff's increased probability of recovery under the new standard.

160 Wolf v. Barkes, 348 F.2d 994, 996 (2d Cir.), cert. denied, 382 U.S. 941 (1965).

${ }^{200}$ Schusselberg v. Colonial Mgmt. Assocs., 389 F. Supp. 733, 735 (D. Mass. 1974) (quoting West Virginia v. Chas. Pfizer \& Co., 314 F. Supp. 710, 740 (S.D.N.Y. 1970), aff'd, 440 F.2d 1079 (2d Cir.), cert. denied, 404 U.S. 871 (1971)); J. Moore \& J. KannedY, supra note 76, I 23.1.24[2], at 23.1-137. For a detailed description of the standards of approval of a § 36(b) settlement, see Krasner v. Dreyfus Corp., 90 F.R.D. 665 (S.D.N.Y. 1981).

${ }^{161}$ Haudek, The Settlement and Dismissal of Stockholder Actions-Part II: The Settlement, 23 Sw. L.J. 765, 807 (1969).

162 "There is nothing in Rule 23.1 which in any way prohibits a corporation from making an out-of-court settlement. . . merely because a derivative action, brought on its behalf, is pending in a federal court." Kahn v. Kaskel, 367 F. Supp. 784, 789 (S.D.N.Y. 1973); see Wolf v. Barkes, 348 F.2d 994, 996-97 (2d Cir.), cert. denied, 382 U.S. 941 (1965); J. MooRE \& J. KENNEDY, supra note 76, II 23.1.24[2], at 23.1-132.

In enacting the original version of the ICA, Congress declined to include an SEC-sponsored provision "that would have forced investment companies to seek court approval before settling claims against 'insiders' that could be the target of derivative suits." Burks v. Lasker, 441 U.S. 471, 484 (1979) (citation omitted).

${ }^{103}$ Kahn v. Kaskel, 367 F. Supp. 784, 789 (S.D.N.Y. 1973).

164 Id. (quoting Wolf v. Barkes, 348 F.2d 994, 997 (2d Cir.), cert. denied, 382 U.S. 941 
The merits of the original claim and the settlement itself can still be considered by the courts. ${ }^{165}$ If the shareholders pursue the original section 36(b) claim, the court will review the settlement pleaded by the adviser as a defense. If the shareholders bring a new action against the directors or the advisers of the investment fund under section 36(a), alleging breach of fiduciary duty in negotiating the settlement, the settlement would then be reviewed by the court. If the independent directors are clearly dominated by the adviser or the affiliated directors, the out-of-court settlement can be enjoined. . $^{166}$

Although judicial review of out-of-court settlements requires further litigation and hence detracts from the capacity of demand to induce settlements, it does not defeat the purposes of demand in general. Extensive litigation would be required only in the few cases of "sham" settlements made without judicial approval. In most cases, the investment company and the defendant adviser will have a great incentive to obtain judicial approval under rule $23.1^{167}$ because court approval can be obtained even over the objection of a shareholder plaintiff, ${ }^{168}$ and is thereafter res judicata. ${ }^{169}$ Since directors and advisers will prefer the benefits of a legitimate settlement of a section $36(\mathrm{~b})$ claim, frequent sham settlements and their attendant litigation are unlikely.

(1965)); J. Moore \& J. KENNEDY, supra note 76, i 23.1.24[2], at 23.1-132. An out-of-court settlement must be "tendered to the court as a defense to the action" in order to have any practical effect. Haudek, supra note 161, at 814; see Dent, supra note 146, at 136 n.198. Note that in certain circumstances a court can enjoin a corporation from settling a claim out of court. See Wolf v. Barkes, 348 F.2d 994, 998 (2d Cir.), cert. denied, 382 U.S. 941 (1965).

${ }^{185}$ In reviewing a challenged settlement, the court looks to the merits of the settlement to determine whether it is "fair, reasonable, and adequate" to all parties concerned. See supra note 159 and accompanying text. Courts should not defer to the directors' business judgment, however, in the case of a plaintiff's challenge to a $\$ 36(\mathrm{~b})$ settlement as courts would defer to a demand decision, because that could permit directors and advisers to avoid their fiduciary duties. See supra note 151 and accompanying text.

${ }^{168}$ Wolf v. Barkes, 348 F.2d 994, 998 (2d Cir.) (dictum), cert. denied, 382 U.S. 941 (1965); J. Moore \& J. KENNEDY, supra note 76, গ 23.1.24[2], at 23.1-132.

${ }_{167}$ Wolf v. Barkes, 348 F.2d 994, 997-98 (2d Cir.), cert. denied, 382 U.S. 941 (1965).

18 Id.; see Clark v. Lomas \& Nettleton Fin. Corp., 79 F.R.D. 641,648 (N.D. Tex. 1978), rev'd on other grounds, 625 F.2d 49 (5th Cir. 1980), cert. denied, 450 U.S. 1029 (1981); Denicke v. Anglo Cal. Nat'l Bank, 141 F.2d 285, 288 (9th Cir.), cert. denied, 323 U.S. 739 (1944); Comment, Compromise of Derivative Claims by a Corporation Without Court Approval, 52 VA. L. REv. 342, 350 (1966).

169 See Comment, supra note 167, at 350-51. The standard for judicial approval is the normal "fair, reasonable and adequate" standard. See supra note 160 and accompanying text. 
c. Deterring Strike Suits. The demand requirement generally serves the practical function of discouraging strike suits by allowing the board of directors to terminate them, subject only to the lenient "business judgment" rule. ${ }^{170}$ If termination is not permitted, however, strike suits become a major concern, since the board's incentive to settle even such frivolous actions is strong. ${ }^{171}$ The section 36(b) action, "created to benefit the corporation, will produce the opposite, unintended result"172 if investment companies are unable to rid themselves of meritless and harmful litigation and the corporate fund is drained by settlement payments on frivolous suits. ${ }^{173}$

Requiring demand, however, helps prevent strike suits even though termination is not permitted. First, even if the independent directors cannot terminate a section 36(b) action, the possibility of removal of the suit from the shareholder's control by the directors taking over prosecution or settling the claim will discourage the initiation of strike suits. ${ }^{174}$ Second, the section $36(\mathrm{~b})(2)$ provision that "approval by the board of directors . . . of such compensation ... shall be given such consideration by the court as is deemed appropriate under all the circumstances"175 suggests that courts should give considerable weight at the summary judgment stage to the opinions of disinterested directors made in good faith after a reasonable investigation of the shareholders' demand. ${ }^{176}$ Thus, the

170 See supra notes $145-48$ and accompanying text.

171 See supra notes 157-58 and accompanying text.

172 Zapata Corp. v. Maldonado, 430 A.2d 779, 787 (Del. 1981).

173 The inability of directors to terminate $\S 36(\mathrm{~b})$ suits may result in investment companies suffering even more strike suits than average corporations, since the mutual fund industry already fits the description of the typical strike suit defendant: "(a) the necessary information and interest can be acquired with relatively little difficulty and expense; (b) the prospective defendant can give concessions considerably larger than the costs of litigation; and (c) the frustration of the defendant's purposes by delay, publicity, or legal defeat will subject him to large financial loss." Note, Extortionate Corporate Litigation: The Strike Suit, 34 Colum. L. Rev. 1308, 1309 (1934). One of the alleged virtues of dispensing with demand in the $\S 36$ (b) situation is that it provides shareholders with "unimpeded access to the courts" in enforcing the $\S 36$ (b) fiduciary duty. Note, supra note 34 , at 1600 . "Unimpeded acess," however, increases the probability of strike suits. Furthermore, maintaining a contemporaneous ownership requirement for plaintiffs bringing $\S 36(\mathrm{~b})$ actions, see id. at 1621, would not prevent strike suits, because a potential plaintiff need only purchase a few shares of the target investment company's stock, hold them until the advisory fee is renegotiated or reapproved (a yearly requirement) and then commence suit.

174 See Dent, supra note 146, at 138-39; Note, supra note 139, at 749.

175 Investment Company Act of 1940 \& 36(b)(2), 15 U.S.C. $\$ 80 \mathrm{a}-35$ (b)(2) (1976).

178 Senate Report, supra note 13, at 6-7, reprinted in 1970 U.S. Cone Cong. \& AD. News at 4903; see Evangelist v. Fidelity Mgmt. \& Research Co., 554 F. Supp. 87, 92 (D. Mass. 1982) ("Courts have, in fact, afforded considerable weight to trustees' decisions in passing on the fairness of advisory fees.") (citation omitted). 
directors' good-faith rejection of demand in meritless section $36(\mathrm{~b})$ actions might persuade courts to dismiss the claims; without demand, courts would have to adjudicate the merits of each section 36(b) claim before being able to dispose of frivolous claims. ${ }^{177}$

3. Minimal Costs of Demand. Demand is also "a simple procedure that is not burdensome to the shareholders."178 "The requirement can be satisfied by simply mailing a copy of the complaint to the board of directors advising them that unless the corporation enforces its rights, the shareholders will institute a derivative action against the alleged wrongdoer,"179 such a requirement would not seem to frustrate the policies embodied in $\S 36(b) .{ }^{180} \mathrm{In}$ fact, if the section 36(b) action cannot be terminated, demand is especially costless to shareholders; the shareholders run only the risk that the directors will take over the suit, in which case they are still protected should the directors reach a sham settlement or prosecute in bad faith. .81 $^{\text {19 }}$

The delay inherent in the demand process, ${ }^{182}$ which might preclude full recovery of excessive fees because of the one-year limit imposed by section 36 on recovery of fees, ${ }^{183}$ can be kept to a rea-

${ }^{277}$ See In re Kauffman Mut. Fund Actions, 479 F.2d 257, 267 (1st Cir.), cert. denied, 414 U.S. 857 (1973).

${ }_{173}$ Weiss v. Temporary Inv. Fund, 692 F.2d 928, 938 (3d Cir. 1982); see Greenspun v. Del E. Webb Corp., 634 F.2d 1204, 1210 (9th Cir. 1980); Markowitz v. Brody, 90 F.R.D. 542, 559 n.16 (S.D.N.Y. 1982); Abrams v. Mayflower Investors, Inc., 62 F.R.D. 361, 368 (N.D. Ill. 1974).

179 Comment, supra note 73 , at 172 (footnote omitted).

180 Id. at 177 n.64.

181 See supra notes $152,163,165$ and accompanying text. Even if termination is not permitted, demand may be costly to plaintiff's attorneys, who, as a result of demand, may lose an opportunity to pursue the derivative claim and earn attorney's fees. This result may reduce attorneys' incentive to search for potential $\S 36(\mathrm{~b})$ violations and bring $\S 36(\mathrm{~b})$ suits. Since the attorney is generally the only party with a real incentive to bring derivative actions (individual shareholders do not gain much by bringing a derivative suit because the recovery goes to the corporation, Joy v. North, 692 F.2d 880, 887 (2d Cir. 1982), cert. denied, $103 \mathrm{~S}$. Ct. 1498 (1983)) requiring demand may result in fewer $\S 36(\mathrm{~b})$ suits being filed. Yet attorneys would still have incentives to bring meritorious $\S 36(\mathrm{~b})$ suits, because those suits would be very likely' to result in a recovery to the corporation and thus result in a significant fee for the attorney.

182 "The demand requirement implies a reasonable time in which directors may analyze the issues and determine whether they believe the company has a grievance." Fox v. Reich \& Tang, Inc., 692 F.2d 250, 261 (2d Cir. 1982), cert. granted sub nom. Daily Income Fund v. Fox, 103 S. Ct. 1271 (1983).

18s Investment Company Act of 1940, § 36(b)(3), 15 U.S.C. \$ 80a-35(b)(3) (1976). The starting date for the computation of damages under $\S 36(\mathrm{~b})$ is one year prior to the filing of the complaint. Id. See generally Krasner v. Dreyfus Corp., 500 F. Supp. 36, 43 (S.D.N.Y. 1980). Thus, any delay on the part of the directors in responding to demand will move the starting date for computation of damages forward to a later date, which may preclude plaintiffs from recovering some damages. Note that in any one particular $\S 36(\mathrm{~b})$ action, delay 
sonable minimum. If the directors do not respond to demand within a reasonable time, the plaintiffs may be permitted to proceed with their suit without waiting for a response. ${ }^{184}$ Three months has been held sufficient time to make a thorough investigation before a failure to act is allowed to satisfy the demand requirement, ${ }^{185}$ though the precise time limit should, of course, be guided by judicial discretion. ${ }^{186}$ Thus, delay in responding to demand would cost the plaintiffs at most three months of excessive fee recovery.

\section{CoNCLUSION}

A thorough consideration of the legislative history of the ICA and section $36(\mathrm{~b})$ and of the functions served by demand in section 36 (b) suits leads to a conclusion that the rule 23.1 demand requirement should be enforced prior to the commencement of a section 36(b) shareholder action alleging breach of fiduciary duty regarding advisory compensation. The shareholder cause of action provided for in section $36(\mathrm{~b})$ is a derivative action. Moreover, demand serves important functions in section $36(\mathrm{~b})$ suits. Demand strengthens the role of independent directors and promotes efficiencies in shareholder suits. The inability of independent directors to terminate shareholder suits does not change this analysis, since the directors' position affords them many opportunities to respond to demand to the benefit of both the shareholders and the corporation. Therefore, demand should be required in section 36 (b) shareholder suits. ${ }^{187}$

Mark S. VanderBroek

will usually change only the particular one-year period of recovery, and probably not decrease the amount of recovery, assuming no interim change in the advisory compensation schedule. But assuming that plaintiffs can recover excessive fees in later years by bringing annual § 36(b) suits, plaintiffs may lose a portion of their possible recovery altogether: the amount of excessive compensation for the period during the year prior to the period in which the directors are evaluating the demand.

1st Mills v. Esmark, Inc., 91 F.R.D. 70, 73 (N.D. Ill. 1981); see Grossman v. Johnson, 674 F.2d 115, 122 (1st Cir.), cert. denied, 103 S. Ct. 85 (1982).

${ }^{18 s}$ Mills v. Esmark, Inc., 91 F.R.D. 70, 73, 73 n.4; see Comment, supra note 73, at 172 n.33 (N.D. Ill. 1981).

${ }^{186}$ See Grossman v. Johnson, 674 F.2d 115, 122 (1st Cir., cert. denied, 103 S. Ct. 85 (1982); supra note 181. Should such discretion prove too costly, Congress could enact a statutory limit on the time within which directors must respond to demand under $\S 36(\mathrm{~b})$.

${ }^{187}$ Just prior to publication, the Supreme Court held, in Daily Income Fund v. Fox, No. 82-1200, slip op. (U.S. Jan. 18, 1984), that the rule 23.1 demand requirement does not apply to an action brought by an investment company shareholder under $\S 36(\mathrm{~b})$, because $\S$ 36 (b) does not create a cause of action, either express or implied, for the investment company itself; thus, the shareholder suit is not a derivative suit. 